\title{
Differential Association of Receptor-G $\beta \gamma$ Complexes with $\beta$-Arrestin2 Determines Recycling Bias and Potential for Tolerance of Delta Opioid Receptor Agonists
}

\author{
Nicolas Audet, ${ }^{1,2}$ Iness Charfi, ${ }^{1,2}$ Ouissame Mnie-Filali, ${ }^{1,2}$ Mohammad Amraei, ${ }^{1}$ Anne-Julie Chabot-Doré, ${ }^{3}$ \\ Magali Millecamps, ${ }^{3}$ Laura S. Stone, ${ }^{3,4,5}$ and Graciela Pineyro ${ }^{1,2,6}$ \\ ${ }^{1}$ Centre de recherche de l'Hôpital Sainte-Justine, Montréal, Quebec H3T 1C5, Canada, ²Département de Pharmacologie, Faculté de Médecine, Université de \\ Montréal, Montréal, Quebec H3T 1J4, Canada, ${ }^{3}$ Alan Edwards Centre for Research on Pain, McGill University, Montreal, Quebec H3A 1A4, Canada, \\ ${ }^{4}$ Department of Pharmacology and Therapeutics, Faculty of Medicine, McGill University, Montreal, Quebec H3G 1Y6, Canada, ${ }^{5}$ Faculty of Dentistry, McGill \\ University, Montreal, Quebec H3A 2B2, Canada, and 'Département de Psychiatrie, Faculté de Médecine, Université de Montréal, Quebec H3T 1J4, Canada
}

Opioid tendency to generate analgesic tolerance has been previously linked to biased internalization. Here, we assessed an alternative possibility; whether tolerance of delta opioid receptor agonists (DORs) could be related to agonist-specific recycling. A first series of experiments revealed that DOR internalization by DPDPE and SNC-80 was similar, but only DPDPE induced recycling. We then established that the non-recycling agonist SNC-80 generated acute analgesic tolerance that was absent in mice treated with DPDPE. Furthermore, both agonists stabilized different conformations, whose distinct interaction with G $\beta \gamma$ subunits led to different modalities of $\beta$-arrestin2 ( $\beta$ arr2) recruitment. In particular, bioluminescence resonance energy transfer (BRET) assays revealed that sustained activation by SNC-80 drew the receptor $\mathrm{C}$ terminus in close proximity of the N-terminal domain of $\mathrm{G} \gamma 2$, causing $\beta$ arr2 to interact with receptors and $\mathrm{G} \beta \gamma$ subunits. DPDPE moved the receptor $\mathrm{C}$-tail away from the $\mathrm{G} \beta \gamma$ dimer, resulting in $\beta$ arr 2 recruitment to the receptor but not in the vicinity of $\mathrm{G} \gamma 2$. These differences were associated with stable DOR- $\beta$ arr2 association, poor recycling, and marked desensitization following exposure to SNC-80, while DPDPE promoted transient receptor interaction with $\beta$ arr 2 and effective recycling, which conferred protection from desensitization. Together, these data indicate that DORs may adopt ligand-specific conformations whose distinct recycling properties determine the extent of desensitization and are predictive of analgesic tolerance. Based on these findings, we propose that the development of functionally selective DOR ligands that favor recycling could constitute a valid strategy for the production of longer acting opioid analgesics.

\section{Introduction}

Opioids are the most efficacious analgesics known, but their use is restricted by the development of tolerance (Dworkin, 2009). Analgesic tolerance is defined as a decrease in potency following repeated drug administration. Depending on the time frame for its development, tolerance may be classified as acute (minutes to hours) or chronic (days to weeks) (Christie, 2008). Reports showing that knockout of $\beta$-arrestin2 ( $\beta$ arr2) reduced acute and chronic tolerance induced by morphine indicate that $\beta$ arr2 plays an important role in the generation of each of these functional

Received July 21, 2011; revised Feb. 10, 2012; accepted Feb. 10, 2012.

Author contributions: N.A., L.S.S., and G.P. designed research; N.A., I.C., O.M.-F., M.A., A.-J.C.-D., M.M., and L.S.S. performed research; N.A. and G.P. analyzed data; N.A. and G.P. wrote the paper.

Research was funded by Natural Sciences and Engineering Research Council of Canada Grant 311997 and Canadian Institutes of Health Research (CIHR) Main Operating Grant Program (MOP) 79432 to G.P. and CIHR MOP 86691 to L.S.S. I.C. received a studentship from Ste-Justine Research Center and A-J.C-D from the CIHR. O.M.-F. received a fellowship from Fonds de la Recherche en Santé de Québec. We are grateful to Dr. M. Bouvier, L. Devi, and T. Hébert for kindly providing BRET pairs used in this study. We thank Dr. L.E. Trudeau and Dr. E. Archer-Lahlou for valuable advice on immunocytofluorescence in neurons and Dr. R. Élie for insightful comments on statistical analysis.

Correspondence should be addressed to Graciela Pineyro, Centre de recherche de l'Hôpital Sainte-Justine, 3175 Chemin de la Côte-Sainte-Catherine, Montréal, QC H3T 1C5, Canada. E-mail: graciela.pineyro.filpo@umontreal.ca. DOI:10.1523/JNEUROSCI.3734-11.2012

Copyright $\odot 2012$ the authors $\quad 0270-6474 / 12 / 324827-14 \$ 15.00 / 0$ adaptations (Bohn et al., 1999, 2000, 2002). At the molecular level, $\beta$ arrs participate in the regulation of opioid receptor signaling (Dang et al., 2011; Raehal and Bohn, 2011), contributing to functional desensitization (Lowe et al., 2002; Qiu et al., 2007) and triggering internalization (Zhang et al., 2005; Qiu et al., 2007). In the case of DORs, internalization may lead to lysosomal trafficking for subsequent degradation (Whistler et al., 2002; Hislop et al., 2009) or may result in receptor recycling (Gomes et al., 2000; Zhang et al., 2008) via a Rab11-dependent mechanism (ArcherLahlou et al., 2009). The sorting of DORs to these alternative destinations has also been shown to involve $\beta$ arr2 (Zhang et al., 2008).

The exact mechanism by which $\beta$ arrs contribute to analgesic tolerance remains unclear (Dang et al., 2011; Nagi and Piñeyro, 2011). Studies using $\mu$-opioid receptor (MOR) agonists indicate that different opioids induce different degrees of tolerance. For example, morphine produces similar analgesic tolerance as oxycodone (Madia et al., 2009), but more so than methadone (Kim et al., 2008) or etorphine (Madia et al., 2009). Since internalization efficacy of these agonists is also distinct (Arttamangkul et al., 2008), tolerance has been linked to differences in agonist ability to recruit $\beta$ arrs and induce MOR sequestration (Martini and 
Whistler, 2007). DOR agonists with distinct internalization profiles also differ in the generation of tolerance. In particular, administration of the internalizing agonist SNC-80 resulted in acute analgesic tolerance that was not observed following the administration of non-internalizing AR-M1000390 (Pradhan et al., 2009). On the other hand, alternative reports indicate that DOR internalization and tolerance may not be strictly related. For example, deltorphin II and SB235863 have similar internalization capacity as SNC-80, but, unlike the latter, they maintain their analgesic efficacy after acute administrations (Beaudry et al., 2009, 2009). Furthermore, despite differences in triggering internalization, long-term administration of SNC- 80 and of ARM1000390 both eventually result in the generation of tolerance (Pradhan et al., 2010).

In the present study, we tested the hypothesis that biased recycling could predict the degree of tolerance induced by DOR agonists. Our results indicate that SNC- 80 generated acute analgesic tolerance whereas DPDPE did not. Assays monitoring DOR trafficking in HEK293 cells and neurons revealed that maximal internalization by both agonists was the same, but only DPDPE elicited receptor recycling. Importantly, BRET assays showed that differences in recycling resulted from stabilization of ligandspecific conformations that established distinct interactions with $\mathrm{G} \beta \gamma$ subunits and $\beta$ arr2.

\section{Materials and Methods}

\section{DNA constructs}

Constructs encoding human DORs fused to either the green fluorescent (GFP) or yellow green fluorescent protein (YFP) were generated by subcloning the entire coding sequence (excluding the stop codon) of the receptor into pGFP-N2 (PerkinElmer Life) or pEYFP-N2 (BD Biosciences) vectors, to produce a fusion protein in which the receptor was separated from the corresponding fluorophore by a seven-amino acid linker (Breit et al., 2006). Plasmids encoding GFP or YFP fused at the $\mathrm{N}$ terminus of human $\mathrm{G} \gamma 2$ were obtained by subcloning the human $\mathrm{G} \gamma 2$ coding sequence into GFP or YFP vectors (Galés et al., 2005). The recombinant plasmid encoding for human $\mathrm{G} \alpha_{\mathrm{i} 1}$-Luc91 was prepared using a flexible linker to insert the coding sequence of humanized Renilla luciferase (RLuc; PerkinElmer Life Sciences) into that of human $\mathrm{G} \alpha_{\mathrm{i1}}$ between residues Leu91 and Lys92 (Audet et al., 2008). The GFP10-EpacRluc BRET ${ }^{2}$-cAMP biosensor was constructed in three steps as described by Leduc et al. (2009). First, GFP10, the linker GSAGT-(Acc65I/ HindIII)-KLPAT, and Rluc were inserted in pcDNA3.1/Zeo (Invitrogen) (Hamdan et al., 2007). Part of human Epac1 (residues 144-881) was then amplified by PCR, digested by Acc65I-HindIII, and inserted using the same restriction sites between GFP10-GSAGT and KLPAT-Rluc3 in pCDNA3.1/Zeo. Finally, the substitutions T781A and F782A were introduced by PCR to remove the Rap1-binding site of Epac1. Murine DORs tagged with the Flag epitope at the $\mathrm{N}$ terminus were a generous gift from Dr. M. von Zastrow (University of California at San Francisco, San Francisco, CA).

\section{Cell culture and transfections}

Immortalized cell lines. Human embryonic kidney 293 (HEK293) cells were cultured in DMEM supplemented with $10 \%$ fetal bovine serum, 2 $\mathrm{mm}$ L-glutamine, $100 \mathrm{unit} / \mathrm{ml}$ penicillin-streptomycin, at $37^{\circ} \mathrm{C}$ in a humidified atmosphere at $95 \%$ air and $5 \% \mathrm{CO}_{2}$. For transient expression of recombinant proteins, HEK293 cells were seeded at a density of $3 \times 10^{6}$ cells in $100 \mathrm{~mm}$ Petri dishes, cultured for $24 \mathrm{~h}$, and transfected with vectors encoding BRET constructs for DORs, G-protein subunits, or $\beta$ arr2 in combination with complementary signaling partners, as detailed below. Transfections were done with polyethylenimine (Polysciences) according to a previously published protocol (Boussif et al., 1995). For trafficking and binding assays, HEK293 cells were stably transfected with Flag-DORs. Monoclonal cell lines were produced using Lipofectamine (Invitrogen) to transfect $6 \mu \mathrm{g}$ of DNA/100 mm Petri dish followed by selection with G418 (500 $\mu \mathrm{g} / \mathrm{ml})$. For cAMP accumulation assays, HEK293-Flag-DOR cells were plated onto $100 \mathrm{~mm}$ Petri dishes and transfected with $3 \mu \mathrm{g}$ of the GFP10-Epac-Rluc BRET2-cAMP biosensor using Lipofectamine (Invitrogen). Cells were then subject to selection using hygromycin $(50 \mu \mathrm{g} / \mathrm{ml})$.

Primary neuronal cultures. Primary neuronal cultures for use in immunofluorescence assays were prepared from rat postnatal prefrontal cortex (P0-P2) using a procedure adapted from a previously described method (Fasano et al., 2008). Briefly, pups were cryoanaesthetized, their brains rapidly removed and transferred into ice-cold dissociation solution $\left(\mathrm{NaSO}_{4} 90 \mathrm{~mm} ; \mathrm{K}_{2} \mathrm{SO}_{4} 30 \mathrm{~mm} ; \mathrm{MgCl}_{2}\right.$ 5,8 mм; $\mathrm{CaCl}_{2} ; \mathrm{HEPES} 10 \mathrm{~mm}$; glucose $20 \mathrm{~mm}$; $\mathrm{pH} 7,4)$. The prefrontal cortex was dissected and digested in papain solution ( 20 units per $\mathrm{ml} ; 40 \mathrm{~min}$ at $37^{\circ} \mathrm{C}$ ), following which the product was passed through Pasteur pipettes of progressively decreasing diameter for mechanical dissociation. The suspension obtained was centrifuged, cells resuspended, and diluted to a density of 2.5 million per milliliter before plating on glass coverslips precoated with collagen/polyL-lysine (each at $0.1 \mathrm{mg} / \mathrm{ml}$ ). Cells were cultured in NeuroBasal A medium supplemented with B27 (4\%), 100 unit/ml penicillinstreptomycin, Glutamax (2\%), and fetal bovine serum (10\%) for $24 \mathrm{~h}$. At this time, coverslips were transferred from their home dish to a 6-well plate containing $2 \mathrm{ml}$ of NeuroBasal A medium/well and transfected with Flag-DORs ( $8 \mu \mathrm{g}$ of DNA/well) by means of a modified calcium phosphate transfection protocol (Shieh et al., 1998). Briefly, a calcium phosphate/DNA precipitate was formed in HEPES-buffered saline ( $\mathrm{pH} 7.03$ ) and was added drop wise to the NeuroBasal A medium. After $30 \mathrm{~min}$ transfection, neurons were washed in Hank's balanced salt solution and returned to their original culture medium.

\section{Evaluation of DOR trafficking in HEK293 cells}

ELISA-based assays. Measurement of surface-expressed receptors and quantification of receptor internalization was assessed using an ELISAbased method adapted from a previously published protocol (ArcherLahlou et al., 2009). HEK293 cells stably expressing Flag-DORs were seeded at a density of $10^{5}$ cells/well and grown on 24 -well polylysinecoated plates for $48 \mathrm{~h}$. The day of the experiment, vehicle, DPDPE, or SNC-80 $(1 \mu \mathrm{M})$ were introduced in new incubation medium containing DMEM/HEPES $20 \mathrm{mM}$ for the indicated times. The internalization reaction was stopped by addition of cold PBS. After three PBS washes, cells were fixed for $15 \mathrm{~min}$ at $4^{\circ} \mathrm{C}$ in paraformaldehyde (3\%) and nonspecific binding was blocked by incubation with PBS/BSA $1 \% / \mathrm{CaCl}_{2} 1 \mathrm{~mm}$ at room temperature (RT) for $30 \mathrm{~min}$. Cells were subsequently incubated with anti-FLAG M1 antibody (1:1000; Sigma-Aldrich) for $1 \mathrm{~h}$ (RT), washed three times, and incubated with peroxidase-conjugated (HRP) anti-mouse antibody (1:8000; GE Healthcare) for $30 \mathrm{~min}$. After extensive washing, $200 \mu$ l of the HRP substrate $o$-phenylenediamine dihydrochloride (SIGMA FAST OPD, Sigma-Aldrich) was added to each well. The reaction was allowed to proceed for $8 \mathrm{~min}$ and stopped using $50 \mu \mathrm{l}$ of $3 \mathrm{~N}$ $\mathrm{HCl}$. Two-hundred microliters of the mix were then transferred to a 96-well plate for optical density (OD) evaluation at $492 \mathrm{~nm}$ in a microplate reader (Victor3; PerkinElmer). OD readings corresponded to the signal generated by receptors at the cell surface. The amount of surface receptors internalized following exposure to agonists was calculated by subtracting OD obtained in the presence of agonist from the one obtained in its absence. Results were expressed as percentage of receptors initially present at the membrane according to the following calculation: $100 \times\left(\mathrm{OD}^{\text {Basal }}-\mathrm{OD}^{\text {Stimulated }}\right) /\left(\mathrm{OD}^{\text {Basal }}\right)$ where $\mathrm{OD}^{\text {Basal }}$ and $\mathrm{OD}^{\text {Stimulated }}$ correspond to the signal obtained in absence or presence of agonist respectively.

Recycling of internalized receptors to the plasma membrane was estimated using a variant of the assay described above. One hour before inducing internalization with a single dose of DPDPE or SNC-80 (1 $\mu \mathrm{M}$; $30 \mathrm{~min}$ ), protein synthesis was blocked with $10 \mu \mathrm{M}$ cycloheximide that remained present throughout the duration of the assay. At the end of the internalization period, the agonist was removed by washing with DMEM at $37^{\circ} \mathrm{C}(3 \times 1 \mathrm{~min})$. Cells were then placed within the incubator to recover in an agonist-free medium (DMEM/HEPES/cycloheximide) for increasing periods of time. In experiments using naltrindole $(1 \mu \mathrm{M})$, naloxone $(1 \mu \mathrm{M})$, or morphine $(10 \mu \mathrm{M})$, these drugs were introduced immediately after agonist washout and remained present in the incuba- 
tion medium throughout recovery. Experiments were stopped by addition of cold PBS, and the steps to label membrane DORs proceeded as described in the previous paragraph. The amount of internalized receptors that recycled back to the surface was expressed as percentage of receptors internalized following exposure to the agonist.

Flow cytometry assays. HEK293 cells stably expressing FLAG-DORs were incubated with vehicle (DMSO 0,01\%), D-Pen-2,5-enkephalin (DPDPE), or (+)-4-[(aR)-a-((2S,5R)-4-Allyl-2,5-dimethyl-1-piperazinyl)-3-methoxybenzyl]- $N, N$-diethylbenzamide (SNC-80) $(1 \mu \mathrm{M})$ for the indicated time periods. At the end of treatment, cells were washed three times in ice-cold PBS and subsequently resuspended in Tyrode's solution ( $140 \mathrm{~mm} \mathrm{NaCl}, 2,7 \mathrm{~mm}$ $\mathrm{KCl}, 1 \mathrm{~mm} \mathrm{CaCl}$, 12 mm NaHCO3, 5,6 mm D-glucose, 0,49 mm MgCl2, 0,37 $\mathrm{mM} \mathrm{NaH}_{2} \mathrm{PO}_{4}, 25 \mathrm{~mm}$ HEPES pH 7,4) at $4^{\circ} \mathrm{C}$. Nonspecific sites were blocked with Tyrode containing $1 \% \mathrm{BSA}$ for $30 \mathrm{~min}\left(4^{\circ} \mathrm{C}\right)$ and surface receptors were then labeled by successive incubation with first (1:1000; anti-FLAG rabbit Sigma-Aldrich) and second (1:1000; goat anti-rabbit, Alexa Fluor 488, Invitrogen) antibodies (30 $\mathrm{min})$. After labeling, cells were washed two times with Tyrode's solution and Flag-DORs present at the membrane were quantified by flow cytometry on a FACsCalibur flow cytometer (BD Biosciences). Internalization was calculated by subtracting membrane fluorescence generated by treated samples from fluorescence produced in vehicle-treated cells. Results were expressed as a percentage of membrane labeling in the absence of ligand.

\section{Evaluation of DOR trafficking in neurons}

Immunocytochemistry experiments were performed $2 \mathrm{~d}$ after transfection. Labeling of surface Flag-DORs was done by introducing $\mathrm{Ca}^{2+}$ dependent mouse anti-Flag M1 antibody (1:100; Sigma) to the incubation medium 30 min before vehicle (DMSO 0,01\%), DPDPE, or SNC-80 $(10 \mu \mathrm{M})$. Following treatments of increasing durations (15-120 $\min )$, neurons were washed in $\mathrm{Ca}^{2+}$-free $\mathrm{PBS}\left(3 \times 1 \mathrm{~min}\right.$, at $\left.37^{\circ} \mathrm{C}\right)$. These washes allowed us to remove treatment drugs as well as antibody bound to surface receptors, thus ensuring that only internalized Flag-DORs that were protected from washes conserved their first antibody labeling (Vargas and Von Zastrow, 2004). In experiments monitoring internalization, washed cells were immediately fixed with $4 \%$ PFA and permeabilized in PBS/0.1\%Triton. Nonspecific sites were blocked with PBS/BSA 1\% (10 $\mathrm{min}$ at RT), and neurons were then exposed to second antibody (donkey anti-mouse Alexa-488; 1:1000; Invitrogen). Images were acquired using a FluoView 1000 confocal laser-scanning microscope (Olympus). Mean cytosolic labeling intensity was quantified in cells that had been exposed to vehicle or agonist for $60 \mathrm{~min}$, using ImageJ according to a previously described method (Scherrer et al., 2006). Briefly, nuclear integrated intensity was subtracted from the integrated intensity present within the perimeter of the neuron soma. The resulting value was divided by the area comprised between the nuclear and outer perimeters of the cell to yield mean cytosolic intensity. Nuclear fluorescence was considered as the background.

In experiments assessing receptor recycling, cells were labeled with first antibody as above and exposed to agonist or vehicle for $60 \mathrm{~min}$. Following treatment, neuron cultures were washed in $\mathrm{Ca}^{2+}$-free PBS $\left(3 \times 5 \mathrm{~min}\right.$, at $\left.37^{\circ} \mathrm{C}\right)$ and returned to the incubator for $60 \mathrm{~min}$ recovery in neurobasal medium. After recovery, cells were fixed and processed as above to assess intracellular fluorescence. For evaluation of surface labeling, neurons that had recovered from agonist exposure were washed with PBS and exposed to second antibody without being permeabilized. Recycling was determined from two complementary measures: (1) evaluating intracellular fluorescence that remained present after recovery from agonist exposure, and (2) counting the number of cells that recovered surface labeling following incubation in the absence of ligand. In total, four independent experiments were performed in which $8-28$ neurons/ condition were sampled.

\section{Intermolecular BRET assays}

All BRET assays were performed in HEK293 cells. The effect of sustained agonist exposure on DOR-G-protein interaction was assessed using a methodology that we had previously developed and validated for detection of ligand-induced conformational changes within DOR-G-protein complexes (Galés et al., 2005, 2006; Audet et al., 2008; Audet and Piñeyro,
2011). Briefly, $100 \mathrm{~mm}$ Petri dishes plated with HEK293 cells were transfected with: (1) DOR-GFP ( $8 \mu \mathrm{g})$, G $\alpha$ il-Luc $(1 \mu \mathrm{g}), \mathrm{G} \beta 1(4 \mu \mathrm{g})$, and $\mathrm{G} \gamma 2$ $(4 \mu \mathrm{g})$ or (2) DOR-Luc $(0.25 \mu \mathrm{g})$, GFP-G $\gamma 2(6 \mu \mathrm{g})$, G $\alpha \mathrm{il}(4 \mu \mathrm{g})$, and $\mathrm{G} \beta 1(4 \mu \mathrm{g})$. These BRET constructs have been previously shown to support normal signaling and to establish specific interactions among themselves (Galés et al., 2005, 2006; Audet et al., 2008). Two days after transfection, HEK293 cells expressing different BRET pairs and their accessory subunits were exposed to vehicle, DPDPE, or SNC-80 $(1 \mu \mathrm{M})$ for $60 \mathrm{~min}$. At the end of treatment, cells were washed three times ( $1 \mathrm{~min}$ each) with $\mathrm{PBS}$ at $37^{\circ} \mathrm{C}$, before distributing them into 96-well microplates (white Optiplate; PerkinElmer Life Sciences). The Rluc substrate, DeepBlueC coelenterazine (PerkinElmer Life Sciences), was manually added into each well to a final concentration of $5 \mu \mathrm{M}$, and BRET2 readings were obtained $2 \mathrm{~min}$ after substrate addition (Galés et al., 2005; Audet et al., 2008). In experiments assessing the acute effect of naltrindole $(1 \mu \mathrm{M})$ on cells that had been preexposed to DPDPE and SNC-80, HEK293 cells were treated and washed as above and the antagonist was introduced $2 \mathrm{~min}$ before coelenterazine. BRET2 readings were obtained using a modified top-count apparatus (TopCount; NXTTM, Packard Bioscience) that allows the sequential integration of the signals detected in the $370-450 \mathrm{~nm}$ and $500-530 \mathrm{~nm}$ windows. The BRET2 signal generated by each sample was determined by calculating the ratio of the light emitted by GFP ( $500-530 \mathrm{~nm}$ ) over the light emitted by Rluc (370-450 $\mathrm{nm})$. BRET2 values were then corrected by subtracting the background signal (detected when the Rluc-tagged construct was expressed without acceptor) from the BRET signal detected in cells coexpressing both Rluc and GFP (netBRET).

For assessing $\beta$ arr2 recruitment, BRET1 assays were conducted using a modified version of a protocol that we had previously optimized for this purpose (Azzi et al., 2003). HEK293 cells grown in $100 \mathrm{~mm}$ Petri dishes

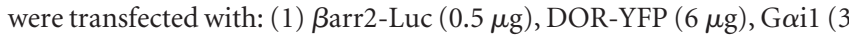
$\mu \mathrm{g}), \mathrm{G} \beta 1(3 \mu \mathrm{g})$, and $\mathrm{G} \gamma 2(3 \mu \mathrm{g})$ or (2) $\beta$ arr2-Luc $(0.5 \mu \mathrm{g})$, YFP-G $\gamma 2$ (3 $\mu \mathrm{g}), \mathrm{G} \alpha \mathrm{il}(3 \mu \mathrm{g}), \mathrm{G} \beta 1(3 \mu \mathrm{g})$, and Flag-DORs $(6 \mu \mathrm{g})$. The ability of the $\beta$ arr2-Luc construct to support normal DOR internalization as well as the specificity of its interaction with DOR-YFP or YFP-G $\gamma 2$ were established before its use (data not shown). Two days after transfection, HEK293 cells were used to monitor one of the following: (1) the kinetics of Barr2-Luc recruitment to DOR-YFP or YFP-G $\gamma 2$; (2) the effect of sustained agonist exposure on each of these BRET pairs, or (3) the BRET signal generated by $\beta$ arr2-Luc/DOR-YFP and $\beta$ arr2-Luc/YFP-G $\gamma 2$ pairs at different times during recovery from agonist treatment. For kinetic assays cells were suspended in PBS (RT), transferred to 96 well plates, and introduced into a Victor3 plate reader (PerkinElmer Life Sciences) in which coelanterazine $\mathrm{h}(1 \mu \mathrm{g} / \mathrm{ml})$ was automatically injected into each well. DPDPE or SNC-80 $(10 \mu \mathrm{M})$ were injected 5 min later, and BRET1 measures were obtained every $18 \mathrm{~s}$ for a period of $6 \mathrm{~min}$. For the two other assays, cells were kept in the incubator at $37^{\circ} \mathrm{C}$ and treated with DPDPE or SNC-80 $(1 \mu \mathrm{M})$ for 30 or $60 \mathrm{~min}$. At the end of treatment, cells were washed with PBS $\left(3 \times 1 \mathrm{~min}, \mathrm{DMEM}, 37^{\circ} \mathrm{C}\right)$ and either immediately redistributed to 96-well plates for BRET1 readings, or were returned to the incubator to recover from treatment before BRET measures were taken. BRET1 readings were obtained 5 min after manual addition of coelenterazine h using $440-480$ and $520-550 \mathrm{~nm}$ filters, to respectively monitor Rluc and YFP emissions. Corrected netBRET1 values were obtained as above.

\section{Intramolecular BRET for evaluation of cAMP accumulation}

Changes in intracellular cAMP levels were assessed by means of an EpacBRET2 biosensor (Leduc et al., 2009), which undergoes conformational changes upon cAMP binding (Barak et al., 2008). These conformational changes modify the basal signal generated by donor-acceptor pairs located at the C- and N-terminal ends of the biosensor, thus allowing to monitor variations in second messenger levels by monitoring changes in BRET (Barak et al., 2008; Leduc et al., 2009). Specifically, HEK293 cells stably expressing Flag-DORs and the Epac-BRET cAMP biosensor (Leduc et al., 2009) were seeded at a density of 5000 cells/well and grown on 96-well polylysine-coated plates for $48 \mathrm{~h}$. The day of the experiment, medium was replaced with fresh DMEM/20 mM HEPES and $1 \mathrm{~h}$ before exposure to DPDPE, SNC-80 (1 $\mu \mathrm{m} ; 60 \mathrm{~min}$ ) or vehicle (DMSO 0.01\%) 
cells were treated with $10 \mu \mathrm{M}$ cycloheximide, which was allowed to remain in the incubation medium throughout the experiment. In experiments in which monensin $(50 \mu \mathrm{M})$ was used, the drug was introduced into the incubation medium together with cycloheximide and also remained present throughout the experiment. At the end of treatment with DPDPE or SNC-80, cells were washed $(2 \times 1 \mathrm{~min})$ with PBS at $37^{\circ} \mathrm{C}$ and were immediately incubated with Tyrode's solution containing $20 \mu \mathrm{M}$ forskolin, $750 \mu \mathrm{M}$ isobutyl-methyl-xanthine (IBMX), and indicated DPDPE concentrations. After 3 min incubation with forskolin, IBMX, and DPDPE, DeepBlueC coelenterazine was added into each well to a final concentration of $5 \mu \mathrm{M}$. BRET2 readings were obtained 9 min after substrate addition to allow for cAMP accumulation to take place. Alternatively, cells were washed $(3 \times 1 \mathrm{~min})$ with DMEM/20 mM HEPES at $37^{\circ} \mathrm{C}$ and returned to the incubator to recover for $30 \mathrm{~min}$ before cAMP production was assessed. Inhibitory dose-response curves were obtained by subtracting BRET ratios obtained in the presence of increasing concentrations of DPDPE from basal ratios. Values obtained in presence or absence of monensin were each normalized to the maximal inhibition induced by DPDPE in their corresponding controls. Before carrying out experiments, the ability of the biosensor to detect changes in cAMP production was compared with a previously described radiometric method (Audet et al., 2005) $\mathrm{EC}_{50}$ values for DPDPE-mediated modulation of cAMP production were $7 \pm 1$ and $4 \pm 1 \mathrm{nM}$ for radiometric and BRETbased assays, respectively $(n=3-6)$.

\section{Coimmunopurification and Western blot}

This procedure was adapted from a previously described method (Archer-Lahlou et al., 2009). Briefly, HEK293 cells were transfected with Barr2-Luc (0.5 $\mu \mathrm{g})$, YFP-G $\gamma 2(3 \mu \mathrm{g})$, G $\alpha$ i1 $(3 \mu \mathrm{g}), \mathrm{G} \beta 1(3 \mu \mathrm{g})$, and Flag-DORs $(6 \mu \mathrm{g})$. Two days later, HEK293 cells were treated with DPDPE or SNC-80 (1 $\mu \mathrm{M} ; 30 \mathrm{~min})$, and, at the end of incubation, they were either immediately used for membrane preparation or washed $(3 \times$ $1 \mathrm{~min}, \mathrm{DMEM}, 37^{\circ} \mathrm{C}$ ) and allowed to recover for $30 \mathrm{~min}$ before their use. Membranes were prepared by suspending cells in lysis buffer $(5 \mathrm{~mm}$ Tris pH 7,4, 3 mм MgCl2, 2 mм EDTA, 1 mм NaF, 1 mm Na3VO4, $5 \mu \mathrm{g} / \mathrm{ml}$ leupeptine, $5 \mu \mathrm{g} / \mathrm{ml}$ soybean trypsin inhibitor, and $10 \mu \mathrm{g} / \mathrm{ml}$ benzamidine;) and homogenizing them in an ultraturax (IKA). Following a short centrifugation at $500 \times g$ to pellet mitochondria and nuclei, the supernatant containing membranes and cytosol was recovered and centrifuged at $30,000 \times g$ for $20 \mathrm{~min}$. The resulting membrane pellet was resuspended in lysis buffer for a second round of centrifugation $(30,000 \times g ; 20 \mathrm{~min})$. At the end of this second round, the membrane pellet was suspended in solubilization buffer $(0.5 \% \mathrm{~N}$-dodecyl-maltoside, $25 \mathrm{~mm}$ Tris pH 7.4, 140 mм NaCl, 2 mм EDTA, 1 mm NaF, 1 mм Na3VO4, $5 \mu \mathrm{g} / \mathrm{ml}$ leupeptine, 5 $\mu \mathrm{g} / \mathrm{ml}$ soybean trypsin inhibitor, and $10 \mu \mathrm{g} / \mathrm{ml}$ benzamidine) and agitated at $4^{\circ} \mathrm{C}$ for $2 \mathrm{~h}$, following which the solubilized material was centrifuged at 20,000 $\times g$ for $30 \mathrm{~min}$. Flag-DORs were immunopurified from the supernatant by means of an anti-FLAG M2 antibody resin. Briefly, 40 $\mu l$ of antibody-coupled resin equilibrated in solubilization buffer and supplemented with $0.1 \%$ bovine serum albumin (w/v) were added to 500 $\mu \mathrm{l}$ of solubilized membranes and kept overnight at $4^{\circ} \mathrm{C}$ under gentle agitation. The next morning the resin was centrifuged, washed twice with $500 \mu \mathrm{l}$ of solubilization buffer, and four times with $500 \mu \mathrm{l}$ of modified solubilization buffer [containing $0.1 \%$ instead of $0.5 \% \mathrm{~N}$-dodecylmaltoside $(\mathrm{w} / \mathrm{v})]$. The receptor was then eluted by incubating the resin for $10 \mathrm{~min}$ at $4^{\circ} \mathrm{C}$ with $100 \mu \mathrm{l}$ of modified solubilization buffer containing the FLAG peptide $(150 \mu \mathrm{g} / \mathrm{ml})$. This elution was repeated three times, and the eluates were combined and concentrated by membrane filtration over Microcon-30 concentrators (Millipore). SDS sample buffer was then added and samples were used for SDS-PAGE. Resulting gels were transferred onto nitrocellulose (GE Healthcare), and $\beta$ arr2-Luc or YFP$\mathrm{G} \gamma 2$ recovered with Flag-DORs were revealed using mouse anti-Luc (1: 1000 Millipore) or rabbit anti-GFP (1:10,000; Abcam) antibodies, followed by corresponding secondary HRP-conjugated antibodies (1: 40,000; GE Healthcare). Flag-DORs in each sample were detected by probing membranes with rabbit anti-FLAG antibody (1:5000; Sigma) and the corresponding secondary antibody (1:40,000; GE Healthcare). Chemiluminescence detection reagents (GE Healthcare) were used to reveal the blotted proteins, and relative intensities of the labeled bands were analyzed by densitometric scanning using MCID (Imaging Research). Densitometric values were used to calculate $\beta$ arr2-Luc/FlagDOR and YFP-G $\gamma 2 /$ Flag-DOR ratios for each condition.

\section{Radioligand binding assays}

Binding assays were performed in HEK293 cells stably transfected with Flag-DORs. The method used has been previously described (Piñeyro et al., 2001). Briefly, saturation curves were obtained by suspending $25 \mu \mathrm{g}$ of protein in $300 \mu \mathrm{l}$ of PBS and incubating cells for $1 \mathrm{~h}\left(21^{\circ} \mathrm{C}\right)$ at RT with increasing concentrations of $\left[{ }^{3} \mathrm{H}\right]$ naltrindole $(0.05-5 \mathrm{nM})$. For competition binding assays, cells were similarly diluted and incubated with $1.5 \mathrm{~nm}$ $\left[{ }^{3} \mathrm{H}\right]$ naltrindole together with increasing concentration of the unlabeled antagonist. Nonspecific binding was determined in the presence of $10 \mu \mathrm{M}$ naltrindole. Incubation was terminated by rapid filtration in a cell harvester (Inotech) through GF/C filters (Whatman) presoaked in $0.1 \%$ polyethylenimine. Bound radioactivity was measured by scintillation counting, and binding parameters were calculated from nonlinear leastsquares analysis of the experimental data using Prism (Graph-Pad Software).

\section{Surgical procedures, drug treatments, and behavioral measures}

The spared nerve injury model of neuropathic pain was induced in male CD-1 mice as previously described (Decosterd and Woolf, 2000; Shields et al., 2003). Nerve injury-dependent induction of mechanical hypersensitivity was measured using calibrated von Frey filaments according to the up-down method (Chaplan et al., 1994), using filaments selected for mice (Millecamps et al., 2010) and expressed as the 50\% withdrawal threshold in grams. Lower thresholds indicate increased sensitivity. The induction of mechanical hypersensitivity was confirmed 1 month following surgery and DPDPE (10 nmoles), SNC-80 (60 nmoles), or vehicle $(0.3 \%$ tartaric acid in distilled water) were injected intrathecally by direct lumbar puncture (Hylden and Wilcox, 1980). Animals were tested at 15 min intervals for $60 \mathrm{~min}$ and then a second injection was administered. Injections and behavioral measures were performed by two different experimenters, each blind to experimental group.

\section{Statistical analyses}

BRET, binding, and coimmunoprecipitation experiments as well as FACs and ELISA-based assays were analyzed using one-way or two-way ANOVA. cAMP accumulation data were analyzed using three-way ANOVA. Mean cytosolic labeling intensity in neurons was analyzed by two-way ANOVA and the number of cells displaying surface labeling was analyzed with a two-tail paired $t$ test. In every case, unequal groups were orthonormalized by Gram-Schmidt procedure. Post hoc Bonferroni tests were used as required to compare selected groups.

\section{Results \\ DPDPE and SNC-80 display similar internalization but distinct recycling profiles}

Recent reports suggest that biased internalization may predict DOR agonist ability to induce tolerance (Pradhan et al., 2009, 2010). Here, we were interested in establishing the extent to which tolerance may be predicted from the recycling profile of DOR agonists. DPDPE and SNC-80 were chosen as test ligands as they phosphorylate DORs at different residues (Okura et al., 2003), differences that may influence both DOR internalization (Zhang et al., 2005) and recycling (Zhang et al., 2008). Trafficking induced by each agonist was assessed in HEK293 cells and cortical neurons to ensure that if differences between ligands were observed, they would not be due to the cellular background in which receptors were expressed. Internalization was first assessed in cortical neurons, using an antibody feeding technique that allowed us to specifically label surface DORs before exposing them to drug or vehicle (Vargas and Von Zastrow, 2004). At the end of treatment, all receptors remaining at the membrane were stripped of first antibody, such that only DORs that were protected from the wash by internalization would be revealed by subsequent immunofluorescence labeling. Figure $1 A$ shows that 


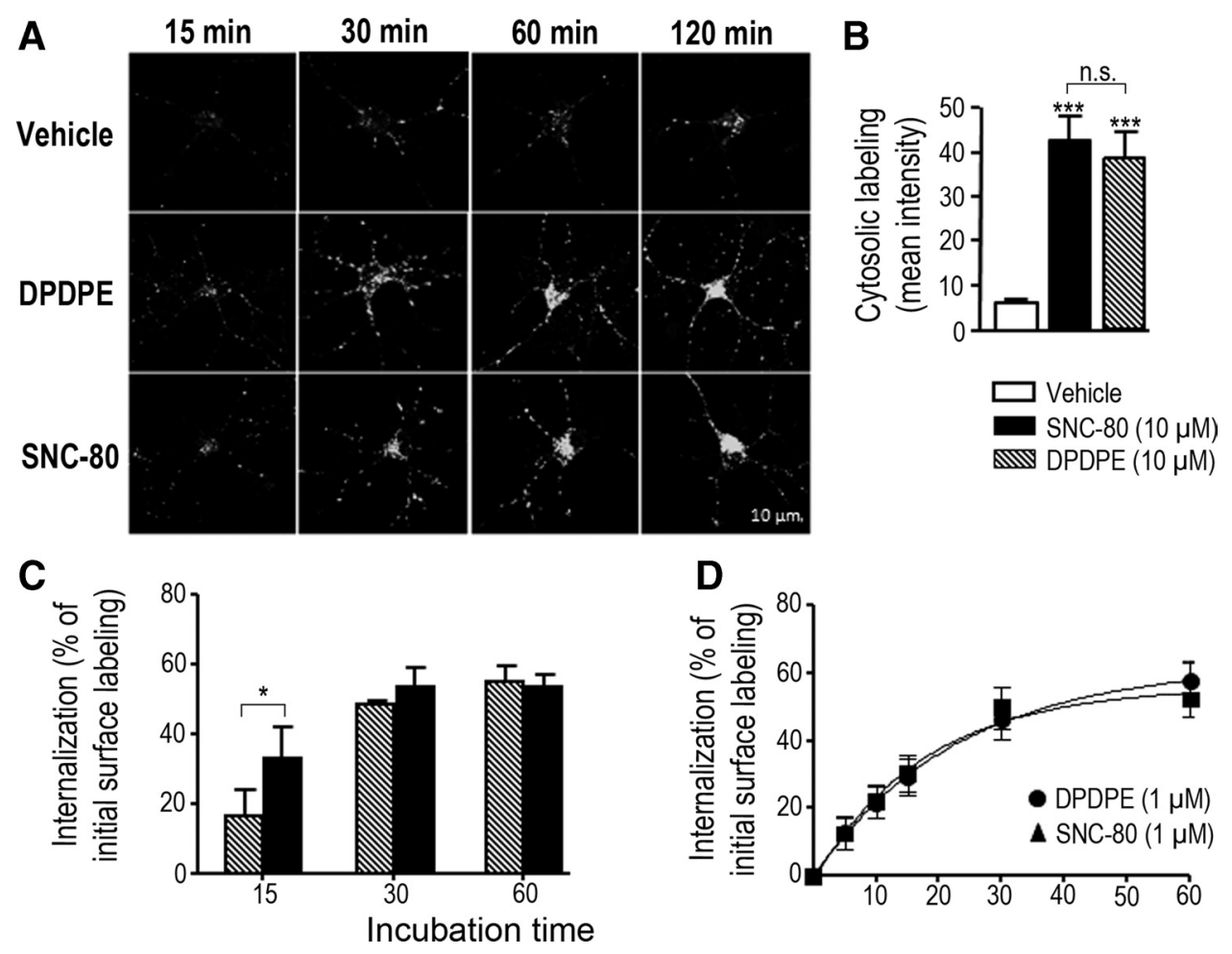

Figure 1. Internalization induced by DPDPE and SNC-80 is similar. A, Cortical neuron cultures were incubated with primary antibody to label surface Flag-DORs. Neurons were then treated with DPDPE or SNC-80 $(10 \mu \mathrm{m})$ for the indicated times. After stopping treatment, antibody bound to surface receptors was stripped, cells were fixed, permeabilized, and labeled with secondary antibody for visualization of intracellular labeling. A representative example from three independent experiments is shown. $\boldsymbol{B}$, Histograms correspond to mean intracellular fluorescence intensity quantified in neurons that were exposed to agonists or vehicle for $1 \mathrm{~h}$ and represent mean \pm SEM of four independent experiments. Internalization data were analyzed together with recycling results shown in Figure $2 B$ by means of repeated measures two-way ANOVA (interaction $F_{(2,15)}=13.02, p<0.001$ ). Bonferroni post hoc for multiple comparisons among internalization groups: ${ }^{* * *} p<0.001$ comparing drugs to vehicle; $p>0.05$ comparison among drugs. C, HEK293 cells expressing Flag-DORs were exposed to DPDPE or SNC-80 (1 $\mu \mathrm{m})$ for the indicated time periods. Receptors at the cell surface were measured by FACs. Results correspond to loss of surface receptors and are expressed as a percentage of receptors present at the membrane before internalization. Data represent mean \pm SEM of four independent experiments that were analyzed by repeated measures two-way ANOVA (interaction $F_{(2,15)}=5.33, p<0.05$ ). Bonferroni posthoc for multiple comparisons: ${ }^{*} p<$ 0.05 comparing DPDPE to SNC-80 at $15 \mathrm{~min}$. D, HEK293 cells expressing Flag-DORs were exposed to DPDPE or SNC-80 $(1 \mu \mathrm{m})$ for the indicated time periods. Receptors at the cell surface were measured by an ELISA-based method, as described in the experimental section. Results correspond to loss of surface receptors and are expressed as a percentage of receptors present at the membrane before internalization. Data represent mean \pm SEM of six independent experiments that were analyzed by repeated measures two-way ANOVA (interaction $F_{(5,55)}=0.8, p>0.05$; difference among drugs $\left.F_{(1,55)}=0.2, p>0.05\right)$.

exposure to vehicle induced a modest, time-dependent increase in intracellular labeling, which is consistent with constitutive internalization of DORs. Exposure to SNC-80 or DPDPE induced a greater time-dependent increase in intracellular immunoreactivity, which was similar for both agonists. Quantification of immunoreactivity confirmed that $60 \mathrm{~min}$ exposure to DPDPE or SNC-80 resulted in similar internalization by both agonists (Fig. $1 B$ ).

To corroborate that the internalization capacity of DPDPE and SNC-80 were similar, endocytosis was assessed in HEK293 using flow cytometry (Fig. 1C) or an ELISA-based assay (Fig. 1D) as alternative approaches. Independent of the method used, internalization measured at 30 and 60 min was the same for both agonists. At a shorter incubation time (15 min), internalization induced by DPDPE was less than that observed for SNC-80, although the difference was only evident in the flow cytometry assay (Fig. 1C).

Several studies performed in heterologous expression systems have shown that internalized DORs are rapidly committed for degradation (Whistler et al., 2002; Hislop et al., 2009). However, data shown in Figure $1 A$ indicate that internalized DORs steadily accumulate within the neuron soma, suggesting the possibility that neuronal DORs could be available for recycling even after prolonged periods of agonist exposure. To verify this possibility,
DOR recycling was assessed in neurons in which internalization had been previously induced by $60 \mathrm{~min}$ exposure to DPDPE or SNC-80 $(10 \mu \mathrm{M})$. Recycling was evaluated by taking two complementary measures: (1) the proportion of internalized receptors that remained trapped in the cytosol $60 \mathrm{~min}$ after agonist removal (Fig. 2A,B) and (2) the number of agonist-treated cells that recovered surface labeling following incubation in the absence of agonist (Fig. 2C,D). To obtain the first measure we quantified intracellular immunoreactivity in neurons that were labeled immediately after exposure to agonist and in neurons that were allowed to recover in the absence of ligand. Intracellular labeling was $44 \pm 7$ immediately after internalization by SNC-80 and $37 \pm 5$ after recovery, indicating that $84 \pm 8 \%(n=4)$ of sequestered DORs remained trapped in the cytosol (Fig. 2 B). In the case of DPDPE, this proportion dropped to $47 \pm 6 \%(n=4)$ with intracellular intensity values of $19 \pm 5$ and $40 \pm 7$ with and without recovery, respectively (Fig. $2 B$ ). To ascertain whether receptors that disappeared from the intracellular compartment were indeed recycling, we verified whether internalized DORs were able to regain the membrane after recovery from treatment. To do so, neurons were exposed to agonist or vehicle, and, at the end of treatment, the agonist was removed and DORs remaining at the membrane were stripped of their first antibody, such that subsequent labeling would only reveal receptors that regained the 
membrane during recovery from internalization. Neurons that were exposed to vehicle displayed no surface labeling, which is consistent with the observation that ligand-independent internalization was minimal (Fig. 1A). On the other hand, membrane immunoreactivity was evident in cells that had been preexposed to DPDPE and SNC-80, indicating a certain level of recycling for each ligand (Fig. $2 C$ ). The amount of receptors that recycled to the membrane following exposure to each of the agonists was estimated by means of a "recovery ratio." This ratio was calculated by dividing the number of immunoreactive neurons that recovered labeling in agonist-treated slides by the total number of surface-labeled neurons present in slides that were not subject to treatment. Figure $2 D$ shows that the recovery ratio in DPDPE-treated neurons was larger than the one obtained in those exposed to SNC-80. Together, results from these experiments indicate that following internalization by SNC-80, DORs remained predominantly trapped within the cytosol, while those internalized by DPDPE abandoned the intracellular compartment to regain the membrane.

DOR recycling was also assessed in HEK293 following $30 \mathrm{~min}$ exposure to DPDPE or SNC-80 $(1 \mu \mathrm{M})$. As shown in Figure $3 A$, none of the receptors internalized by SNC- 80 were able to recycle while $53 \pm 3 \%$ of those internalized by DPDPE reappeared at the membrane. Moreover, saturation and displacement binding assays using $\left[{ }^{3} \mathrm{H}\right]$ naltrindole confirmed that the absence of recycling observed for SNC-80 could not be simply attributed to incomplete drug washout, since $K_{\mathrm{d}}$ (Fig. $3 B$ ) and $B_{\max }$ (see Fig. 6A) values for the radioligand were restored to pretreatment levels following removal of this agonist.

\section{Differences in DOR recycling are consistent with agonist propensity to induce desensitization and acute analgesic tolerance}

Studies using recycling inhibitor monensin or dominant-negative Rab11 mutants indicate that recycling helps reduce the impact of desensitization on DOR responsiveness (Archer-Lahlou et al., 2009). To determine whether the extent of desensitization induced by the two agonists was consistent with their respective recycling patterns, we monitored how $1 \mathrm{~h}$ treatment with SNC-80 or DPDPE $(1 \mu \mathrm{M})$ modified DOR responsiveness to subsequent stimulation by DPDPE. Changes in cAMP production were examined using an EpacBRET2 biosensor (Barak et al., 2008; Leduc et al., 2009) that allows us to monitor intracellular variations in second messenger levels through changes in BRET. In naive cells that had been preexposed to vehicle, incubation with increasing concentrations
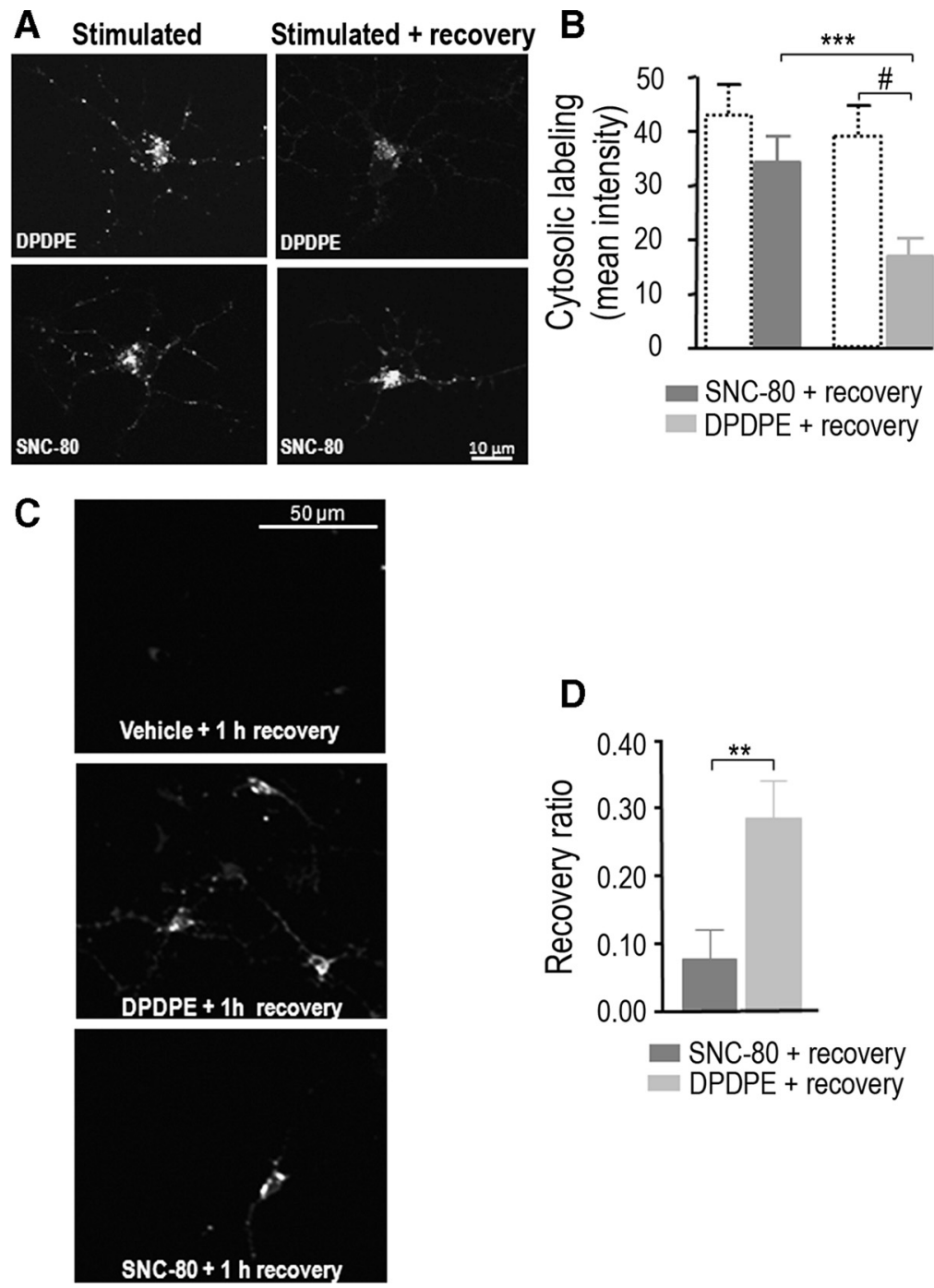

Figure 2. Recycling of neuronal DORs is different following exposure to DPDPE and SNC-80. $A$, Neurons were treated as in Figure $1 A$ following which they were washed and either immediately processed for intracellular labeling (stimulated) or were first allowed to recover for 60 min in the absence of ligand (stimulated + recovery). Labeling of intracellular DORs was done as in Figure $1 A$. The image shows a representative example of one of four independent experiments. $\boldsymbol{B}$, Histograms represent mean intracelIular intensity in neurons that were stimulated and immediately labeled (dashed), or in neurons that were first allowed to recover in the absence of ligand (filled). Note: dashed bars correspond to internalization values in Figure $1 B$. Results represent mean \pm SEM of four independent experiments. Recycling data were analyzed together with internalization results shown in Figure $1 B$ by means of repeated measures two-way ANOVA (interaction $F_{(2,15)}=13.02, p<0.001$ ). Bonferroni post hoc for multiple comparisons: ${ }^{* * *} p<0.001$ comparing recovery by DPDPE and SNC-80; $p<0.001$ comparing stimulated versus stimulated + recovery for DPDPE. C, Neurons were treated and washed as indicated above before allowing them to recover in the absence of ligand. At the end of the recovery period, cells were processed for surface labeling as described in the experimental section. The image shows a representative example of surface labeling obtained in different treatment conditions and corresponds to one example of four independent experiments. $\boldsymbol{D}$, Histograms represent "recovery ratios" obtained following recovery from exposure to DPDPE or SNC-80 and correspond to mean \pm SEM of four independent experiments. "Recovery ratios" were calculated by dividing the number of labeled neurons present in agonist-treated slides by the total number of surface-labeled neurons present in slides that were not subject to treatment. Recovery ratios were analyzed by paired $t$ test; ${ }^{* *} p<0.01$.

of DPDPE induced a dose-dependent decrease in second messenger levels (Fig. 4A,B). Preexposure to either agonist modified DOR responsiveness to DPDPE, as evidenced by a decrease in the agonist's potency and efficacy to inhibit cAMP production. In particular, SNC-80 induced a larger right shift and more pronounced decrease in $E_{\max }$ than those induced by DPDPE (Fig. $4 A$ ), indicating greater desensitization by the former. Importantly, both agonists displayed similar ability to maximally inhibit forskolin-stimulated cAMP production $\left(E_{\max }\right.$ SNC-80:$70 \pm 2 ; E_{\max }$ DPDPE: $-69 \pm 3 ; \mathrm{EC}_{50}$ SNC-80: $5 \pm 1 \mathrm{~nm} ; \mathrm{EC}_{50}$ 

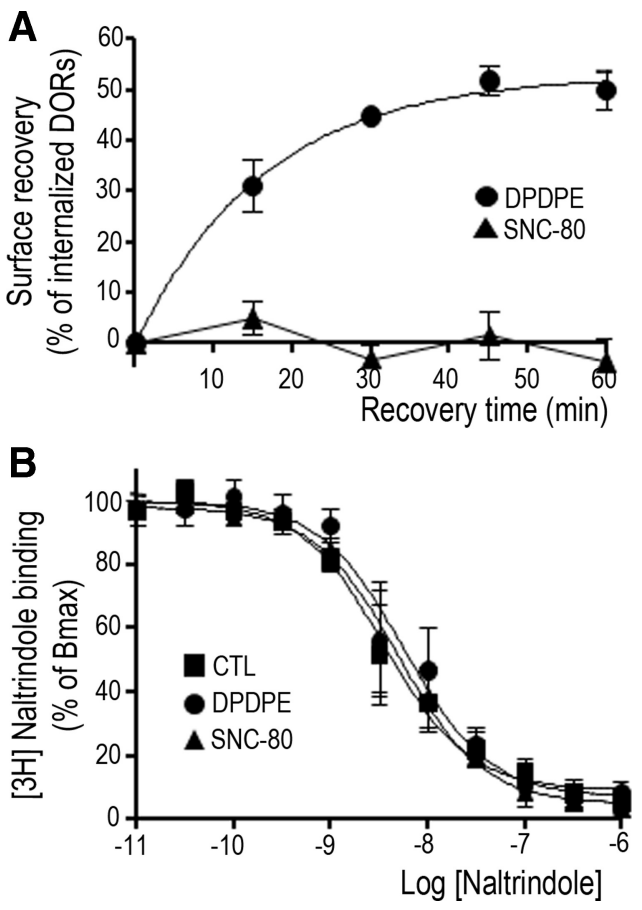

Figure 3. DPDPE and SNC-80 elicit different DOR recycling in HEK293 cells. A, Cells stably expressing wild-type DORs were incubated with SNC-80 or DPDPE (1 $\mu \mathrm{m} ; 30 \mathrm{~min})$ to induce internalization. At the end of treatment, cells were washed to remove agonist and allowed to recover for the indicated periods of time before membrane receptors were assessed using an ELISA-based method. Results were expressed as percentage of internalized DORs and represent mean \pm SEM of 4-8 independent experiments. Curves were compared by mixed two-way ANOVA (interaction $F_{(4,50)}=23.8, p>0.001$; difference among drugs $p<0.001$ ). $\boldsymbol{B}$, HEK293 cells were treated and washed as above before being used in $\left[{ }^{3} \mathrm{H}\right]$ naltrindole displacement assays in which the radioligand $(1.5 \mathrm{~nm})$ was displaced with the indicated concentrations of cold naltrindole. $K_{\mathrm{d}}$ values were calculated from concentrations that inhibited $\left[{ }^{3} \mathrm{H}\right]$ naltrindole binding by 50\% (IC $\left.\mathrm{C}_{50}\right)$ using the Cheng-Prusoff equation. $K_{\mathrm{d}}$ CTLs: $223 \pm 40 \mathrm{pm} ; K_{\mathrm{d}}$ following SNC-80: $302 \pm 42 \mathrm{pm} ; K_{\mathrm{d}}$ following DPDPE: $280 \pm 40 \mathrm{pm}$.

DPDPE: $8 \pm 1 \mathrm{nM} ; p>0.05$; two-way ANOVA; $n=6$ ), which suggests that the observed differences in desensitization were not necessarily efficacy-related. On the other hand, desensitization by DPDPE and SNC-80 were distinctively modified by monensin. In particular, monensin enhanced desensitization by DPDPE but not SNC-80, indicating that only the former relied upon recycling to mitigate functional consequences of desensitization. Apart from its protective role during the actual process of desensitization (Archer-Lahlou et al., 2009), DOR recycling has also been shown to support resensitization once the agonist has been removed (Trapaidze et al., 2000). In contrast, studies performed on MORs indicate that resensitization can take place at the membrane, independent of any type of receptor trafficking (Dang and Christie, 2011). We found that the presence of monensin did not significantly modify resensitization following exposure to either agonist (Fig. $4 \mathrm{~B}$ ). Although these data do not allow us to conclude whether DOR resensitization takes place at the membrane, they show that recovery of DOR responsiveness in the first $30 \mathrm{~min}$ after agonist removal does not require recycling.

Based on the data obtained with monensin, it is possible to conclude that recycling mitigates loss of receptor responsiveness during desensitization by DPDPE but not SNC-80. Thus, one would expect repeated administration of SNC-80 to cause larger loss of functional DORs as compared with DPDPE and consequently a larger degree of tolerance. The latter assumption was tested using an animal model of chronic pain. Several lines of evidence indicate that DORs are specifically involved in modulating chronic pain of inflammatory and neuropathic origin, as follows: (1) DOR function is enhanced in both of these conditions (Cahill et al., 2007), (2) mice with global DOR knock out (Nadal et al., 2006) or with genetic ablation of DORs in nociceptive sensory neurons display enhanced pain behavior in both models (Gaveriaux-Ruff et al., 2011), and (3) administration of selective DOR agonists attenuates pain hypersensitivity, particularly mechanical allodynia (Scherrer et al., 2006; Gaveriaux-Ruff et al., 2011). Consequently, we used a murine model of neuropathic pain to determine whether antiallodynic effects of DPDPE and SNC-80 displayed different degrees of tolerance. Since mechanisms regulating receptor responsiveness are typically involved in the generation of acute analgesic tolerance (Christie, 2008), we determined whether two successive intrathecal injections of equianalgesic doses of either DPDPE or SNC-80 resulted in differential loss of the analgesic response. Figure $4 C$ shows that mice which received saline injections displayed marked hypersensitivity to mechanical stimuli over the course of repeated testing. Administration of the first injection of DPDPE or SNC-80 similarly reduced pain sensitivity. However, while DPDPE maintained its analgesic efficacy after its second injection, SNC-80 did not, indicating the development of acute analgesic tolerance for the non-recycling agonist.

\section{Sustained activation by DPDPE and SNC-80 stabilized DORs into conformations that distinctively interact with $\mathrm{G} \beta \boldsymbol{\gamma}$ subunits}

The idea that agonist bias in trafficking could contribute to distinct potential for tolerance presupposes the existence of agonistspecific conformations (Urban et al., 2007; Kenakin and Miller, 2010). However, there is no physical evidence confirming whether conformations stabilized by ligands that display distinct trafficking profiles do indeed stabilize different conformations. To design an experiment that would allow us to assess whether DPDPE and SNC-80 stabilized DORs into different conformations, we reasoned that the regulatory events which take place during the development of acute tolerance typically involve desensitization, and consequently changes in receptor G-protein coupling. Hence, if the two agonists were to stabilize DORs into different conformations, then each of these conformations would be expected to distinctively modify DOR interaction with the G-protein. We have previously shown that BRET assays constitute a valuable tool to evaluate acute conformational changes undergone by DORs upon binding of different ligands (Audet et al., 2008; Audet and Piñeyro, 2011). We now used a similar approach to monitor how sustained activation by DPDPE or SNC-80 (1 $\mu \mathrm{M} ; 60 \mathrm{~min})$ modified DOR interactions with G $\alpha \beta \gamma$ subunits. G $\alpha$ il-Luc/DOR-GFP and DOR-Luc/GFP-G $\gamma 2$ were the biosensors used to monitor DOR interaction with G $\alpha \mathrm{il}$ and G $\beta 1 \gamma 2$ subunits, respectively. In keeping with our previous observations, both BRET pairs displayed spontaneous energy transfer, confirming that DORs constitutively associate with G $\alpha$ i1 $\beta 1 \gamma 2$ subunits (Audet et al., 2008). Spontaneous netBRET values generated by G $\alpha \mathrm{il}-\mathrm{Luc} / \mathrm{DOR}-\mathrm{GFP}$ and DOR-Luc/GFPG $\gamma 2$ were $0.051 \pm 0.01$ and $0.37 \pm 0.03(n=4-5)$, respectively. Sustained exposure to either agonist reduced netBRET at the DOR G $\alpha$ il interface (Fig. 5A). In contrast, both agonists had opposing effects at the DOR-Luc/GFP-G $\gamma 2$ pair, with DPDPE decreasing and SNC-80 increasing the spontaneous netBRET signal (Fig. 5C). Given the position of donor/acceptor tags in the different BRET pairs, it is possible to conclude that both agonists caused the receptor $\mathrm{C}$ terminus and $\mathrm{G} \alpha$ subunit to separate from 
A

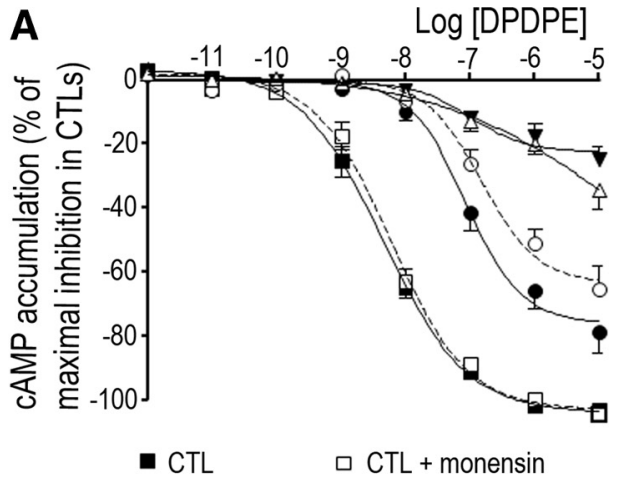

- Des DPDPE ○ Des DPDPE + monensin

- Des SNC-80 $\triangle$ Des SNC-80 + monensin

B

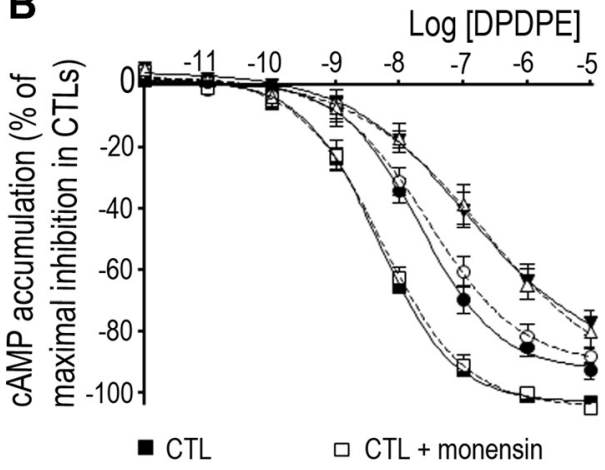

- Res DPDPE o Res DPDPE + monensin

- Res SNC-80 $\triangle$ Res SNC-80 + monensin

C

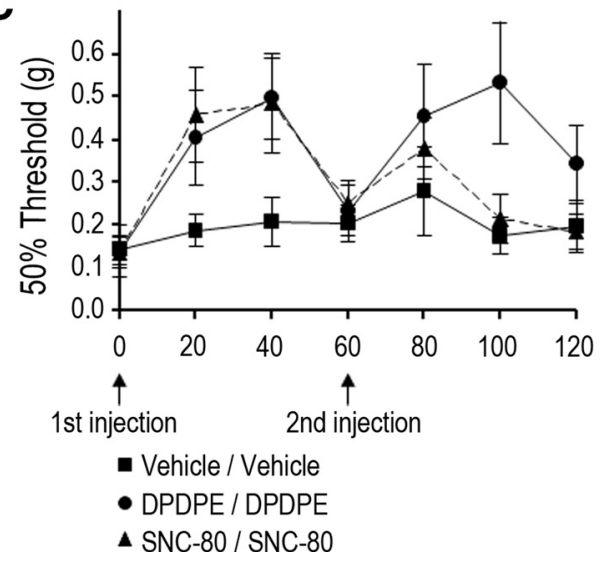

Figure 4. DPDPE and SNC-80 differ in their ability to induce desensitization and acute analgesic tolerance. HEK293 cells were incubated with $10 \mu \mathrm{m}$ cycloheximide and treated or not with monensin $(50 \mu \mathrm{m}$ ) before exposing them to vehicle (DMSO 0.01\%), DPDPE, or SNC-80 (1 $\mu \mathrm{m} ; 60$ $\mathrm{min}$ ). At the end of treatment, cells were washed and either immediately used to monitor CAMP accumulation after agonist-induced desensitization $(\boldsymbol{A})$ or were first allowed to recover in the absence of ligand so as to evaluate resensitization $(\boldsymbol{B})$. Results are expressed as percentage of maximal inhibition obtained in corresponding untreated controls, and correspond to 5-6 independent experiments performed in duplicates. $\boldsymbol{A}$, Desensitization data were analyzed by means of three-way ANOVA (agonist $\times$ monensin $X$ concentration). Interaction for agonist $X$ monensin groups $\left(F_{(2,188)}=7.20, p<0.01\right)$. Bonferroni post hoc for multiple comparisons: control versus desensitization by DPDPE $p<0.001$; control versus desensitization by SNC -80 $p<0.001$; desensitization by DPDPE versus desensitization by SNC-80 $p<0.001$; desensitization by DPDPE versus desensitization by DPDPE + monensin $p<0.001$; desensitization by SNC- 80 versus desensitization by SNC $-80+$ monensin $p>0.05$. $\boldsymbol{B}$, Resensitization data were analyzed as above. Interaction for agonist $\times$ monensin groups was nonsignificant $\left(F_{(2,235)}=\right.$ $1.7, p>0.05)$. Effect of agonist factor: $F_{(2,235)}=267, p<0.001$; effect of monensin factor:
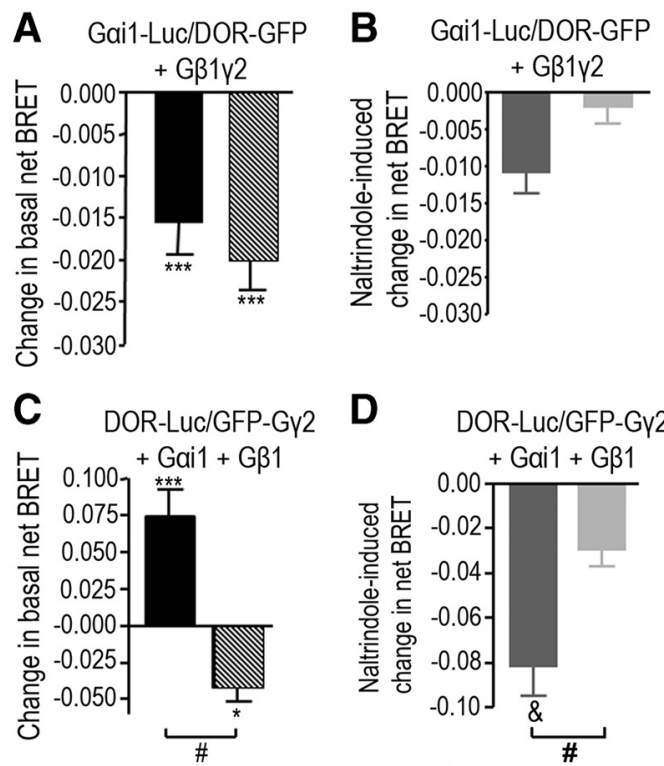

\section{DOR-Luc/GFP-Gy2}

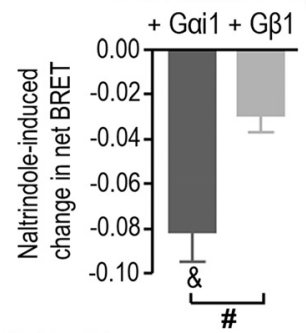

SNC-80 (1 $\mu \mathrm{M}, 60$ mîn)

DPDPE (1 $\mu \mathrm{M}, 60 \mathrm{~min})$

SNC-80 (1 $\mu \mathrm{M}, 60 \mathrm{~min})+\operatorname{NALT}(1 \mu \mathrm{M}, 2 \mathrm{~min})$

DPDPE $(1 \mu \mathrm{M}, 60 \mathrm{~min})+\mathrm{NALT}(1 \mu \mathrm{M}, 2 \mathrm{~min})$

Figure 5. Sustained exposure to DPDPE and SNC-80 stabilized DORs into conformations that distinctively interact with $G \beta \gamma$ subunits. HEK293 cells were transfected with $G \alpha i$-Luc/DOR-GFP $(\boldsymbol{A}, \boldsymbol{B})$ or DOR-Luc/GFP-G $\gamma 2(\boldsymbol{C}, \boldsymbol{D})$ plus indicated accessory proteins. On the day of the experiment they were exposed to DPDPE $(1 \mu \mathrm{M}), \mathrm{SNC}-80(1 \mu \mathrm{M})$, or vehicle $(0.01 \% \mathrm{DMS})$ ) for $60 \mathrm{~min}$. At the end of treatment, cells were resuspended, washed, and transferred to a microplate where coelenterazine was added 2 min before BRET2 measures. Results were expressed as the difference between netBRET values obtained in vehicle and agonist-treated cells, and correspond to mean \pm SEM of $4-5$ independent experiments $(\boldsymbol{A}, \boldsymbol{C})$. In experiments assessing the acute effect of naltrindole $(1 \mu \mathrm{m})$ in cells that had been preexposed to DPDPE or SNC-80, the antagonist was introduced $2 \mathrm{~min}$ before coelenterazine. Results were expressed as the difference between netBRET values obtained in presence or absence of naltrindole $(\boldsymbol{B}, \boldsymbol{D})$. Statistical comparisons were done by repeated measures two-way ANOVA on netBRET values. $(\boldsymbol{A}, \boldsymbol{B})$ : agonist $\times$ naltrindole interaction was not significant $\left(F_{(2,20)}=1.9, p>0.05\right)$; effect of agonist factor $\left(F_{(2,20)}=32.9, p<0.001\right)$, effect of naltrindole factor $\left(F_{(1,20)}=0.6, p>0.05\right)$; Bonferroni for post hoc comparisons showed ${ }^{* *} p<0.001$ comparing drugs to vehicle. (C, D): agonist $\times$ naltrindole interaction $\left(F_{(2,15)}=9.3, p<0.01\right)$, Bonferroni for post hoc comparisons showed ${ }^{*} p<0.05 ;{ }^{* * *} p<0.001$ comparing agonist to vehicle; ${ }^{*} p<0.01$ comparing DPDPE versus SNC-80 in CTL groups and in naltrindole groups; ${ }^{\&} p<0.01$ comparing netBRET values in presence and in absence of naltrindole.

one another. On the other hand, the BRET increase induced by SNC-80 at the DOR-Luc/GFP-G $\gamma 2$ pair indicated that the receptor $\mathrm{C}$ terminus was drawn closer to the N-terminal domain of $\mathrm{G} \gamma 2$. The reduction of this signal by DPDPE implied a separation

\footnotetext{
$F_{(1,235)}=0.75, p>0.05$. Bonferroni for post hoc comparisons showed resensitization following DPDPE versus resensitization following SNC-80, $p<0.001$. C, One month following induction of the spared nerve injury model of neuropathic pain, calibrated von Frey filaments were used to evaluate the reversal of mechanical hypersensitivity following administration of an intrathecal injection of either vehicle, DPDPE or SNC-80. The $50 \%$ withdrawal thresholds ( $g$ ) were then evaluated three times every $20 \mathrm{~min}$, before administering a second identical dose of the corresponding treatment followed by similar assessment. Results are expressed as mean \pm SEM, $n=10-20 /$ treatment group. Data were analyzed using three-way ANCOVA (treatment $\times$ testing over time $\times$ injection) using basal thresholds $(t=0)$ as coregressor $\left(F_{(1,231)}=\right.$ 22.0, $p<0.001$; heterogeneity of regression slope: $\left.F_{(17,214)}=1.15, p>0.05\right)$. Treatment $X$ injection interaction $\left(F_{(1,231)}=5.3, p<0.05\right)$ allowed the following comparisons: effect of first DPDPE injection versus effect of first SNC-80 injection: $p>0.05$; effect of second DPDPE injection versus effect of second SNC -80 injection: $p<0.01$; effect of first versus second DPDPE injection: $p>0.05$; effect of first versus second SNC-80 injection: $p<0.05$.
} 
A

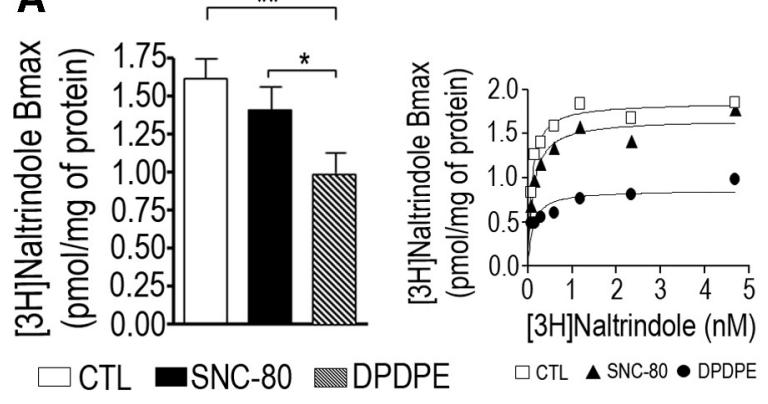

B

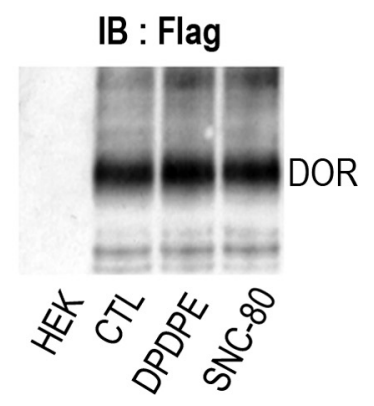

Figure 6. Sustained exposure to DPDPE and SNC-80 stabilized DORs into conformations that were distinctively recognized by $\left[{ }^{3} \mathrm{H}\right.$ ]naltrindole. $\boldsymbol{A}$, HEK293 cells stably expressing Flag-D0Rs were exposed to DPDPE, SNC-80 (1 $\left.\mu \mathrm{m} ; 1 \mathrm{~h}\right)$, or vehicle $(0.01 \%$ DMSO). Following treatment, cells were washed and $\left[{ }^{3} \mathrm{H}\right]$ naltrindole binding was then assessed. Histograms represent mean \pm SEM of $B_{\max }$ binding obtained in four independent experiments. Statistical comparisons were done by repeated measures one-way $\operatorname{ANOVA}\left(F_{(2,6)}=20.9, p<0.01\right)$ using Bonferroni for post hoc comparisons: ${ }^{*} p<0.05$ comparing SNC-80 vs DPDPE; ${ }^{* *} p<0.01$ comparing control versus DPDPE. Right panel corresponds to a representative example of four independent saturation experiments. $\boldsymbol{B}$, HEK293 cells expressing Flag-D0Rs were exposed to agonist or vehicle as above. Following treatment cells were washed and membrane lysates prepared. The solubilization product was then separated by electrophoresis SDS-PAGE and receptor protein was revealed by immunoblot. A representative example of four independent experiments is shown.

of the same two regions. These opposing BRET changes indicate that both agonists induced distinct orientation of the receptor $\mathrm{C}$ terminus relative to $\mathrm{G} \gamma 2$.

The idea that DORs were distinctively modified by sustained exposure to either agonist ( $1 \mu \mathrm{M} ; 60 \mathrm{~min})$ was also supported by binding assays performed in HEK293 cells stably expressing FlagDORs. As shown in Figure 6A, exposure to DPDPE caused a decrease in the total number of sites labeled by $\left[{ }^{3} \mathrm{H}\right]$ naltrindole, a reduction that took place without change in the total amount of receptor protein (Fig. $6 \mathrm{~B}$ ). The latter observation together with the fact that naltrindole affinity for the receptor also remained unchanged (Fig. 3B), allowed us to rule out downregulation and lingering free agonist as possible causes for the apparent loss of antagonist binding sites. Alternatively, $\left[{ }^{3} \mathrm{H}\right]$ naltrindole may have failed to recognize all conformational states stabilized by DPDPE, a phenomenon that has been previously reported for other DOR ligands (Piñeyro et al., 2001). Unlike DPDPE, preexposure to SNC-80 allowed complete recovery of $B_{\max }$ binding (Fig. $6 A$ ), suggesting that $\left[{ }^{3} \mathrm{H}\right]$ naltrindole similarly recognized DORs stabilized by the agonist and those present in naive cells. Furthermore, if reduction in naltrindole binding capacity were due to the radioligand being incapable of recognizing all the conformational states stabilized by DPDPE, one would expect that the population of DORs reacting to naltrindole would be smaller following treatment with this agonist than after exposure to SNC80. Consistent with this interpretation, biosensors assessing DOR interaction with $\mathrm{G} \beta \gamma$ subunits indicated that addition of naltrindole to cells that had been preexposed to SNC-80 resulted in larger BRET changes than addition of the antagonist to cells that were pretreated with DPDPE (Fig. 5D).

\section{Sustained exposure to SNC-80 and DPDPE induced agonist-specific interactions among DORs, G $\beta 1 \gamma 2$ subunits, and $\beta$ arr 2}

Having confirmed that DPDPE and SNC-80 stabilized DORs into distinct conformations, we next sought to characterize the interactions established between each of these conformations and proteins that like $\beta$ arr2 participate in the development of tolerance (Zhang et al., 2008; Dang et al., 2011). To compare $\beta$ arr 2 recruitment to receptors stabilized by DPDPE and SNC-80, we turned to BRET assays, using $\beta$ arr2Luc/DOR-YFP as a biosensor. As shown in Figure 7A, DPDPE and SNC-80 both induced $\beta$ arr 2 recruitment with a half-life of $<2 \mathrm{~min}$, which is in reasonable agreement with previous reports (Molinari et al., 2010). The BRET change induced by SNC-80 was larger than the one induced by DPDPE, a difference that was clearly established within the first 2 min of receptor activation and remained present after sustained exposure to the agonist (Fig. 7B).

BRET data assessing agonist effects on DOR-G-protein interaction indicated that only SNC-80 caused the receptor C terminus to approach to the free end of the $G \beta \gamma$ dimer. We were therefore interested in finding out whether $\beta$ arr2 recruitment by the two agonists would entail differential interaction with $\mathrm{G} \beta \gamma$. To assess this possibility we used a biosensor that would allow us to monitor $\beta$ arr2 recruitment from the vantage point of the $\mathrm{G} \beta \gamma$ dimer, i.e.: $\beta$ arr2Luc/YFP-G $\gamma 2$. Interestingly, only SNC-80 increased BRET at the Barr2-Luc/YFP-G $\gamma 2$ pair (Fig. 7C,D), indicating that this agonist was the only one bringing the regulatory protein in close proximity of the $\mathrm{N}$-terminal domain of $\mathrm{G} \gamma 2$. As for $\beta$ arr 2 interaction with the receptor, differences between DPDPE and SNC-80 appeared rapidly after agonist addition (Fig. 7C) and were maintained over $1 \mathrm{~h}$ of receptor stimulation (Fig. 7D). At this time, BRET changes induced by SNC-80 at $\beta$ arr2-Luc/DOR-YFP and $\beta$ arr2-Luc/YFP-G $\gamma 2$ pairs were respectively two- and six-fold higher than those induced by DPDPE.

$\beta$ arrs are known to influence receptor recycling such that receptors that establish a stable interaction with these regulatory proteins are those that recycle the least (Oakley et al., 1999; Zhang et al., 1999). Moreover, the stability of receptor- $\beta$ arr association is partly determined by the specific phospho-residues different receptor subtypes make available for $\beta$ arr binding (Oakley et al., 1999; Hanson and Gurevich, 2006). Given that DPDPE and SNC-80 phosphorylate DORs at different amino acids (Okura et al., 2003), and since both agonists induce different modalities of $\beta$ arr2 recruitment, we sought to determine whether DOR- $\beta$ arr2 association promoted by each agonist displayed different stability. In a first series of experiments, we used BRET assays to determine the stability of DOR- $\beta$ arr2 association. To do so, we induced $\beta$ arr 2 recruitment by DPDPE or SNC-80 ( $1 \mu \mathrm{M}, 30$ $\mathrm{min})$, and then measured the time required by $\beta$ arr2-Luc/DORYPP and $\beta$ arr2-Luc/YFP-G $\gamma 2$ pairs to recover their basal BRET values upon the removal of each agonist. As before, BRET changes monitored at the $\beta$ arr2-Luc/DOR-YPP pair revealed significant $\beta$ arr2 recruitment by DPDPE (Fig. $8 A$ ) and by SNC-80 (Fig. $8 \mathrm{~B}$ ). Furthermore, cells that were exposed to DPDPE recovered prestimulation BRET values within $30 \mathrm{~min}$ of agonist removal (Fig. $8 A$ ), while the signal remained unchanged in cells that recovered from exposure to SNC-80 (Fig. 8 B). Also in keeping with our previous observations, SNC-80 was the only of the two agonists to increase BRET at the $\beta$ arr2-Luc/YFP-G $\gamma 2$ pair (Fig. $8 C$ ), and, similar to $\beta$ arr2 interaction with the receptor, BRET levels did not attain prestimulation values upon agonist removal (Fig. $8 D$ ). Finally, we verified whether coexpression with Barr2 could have modified agonist-induced conformational 

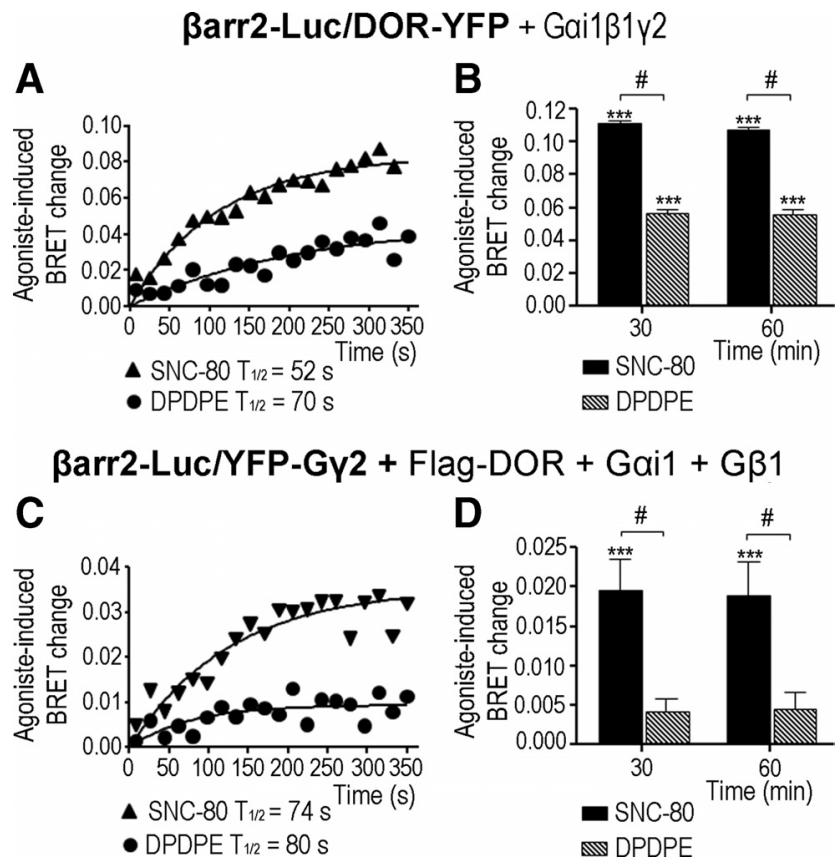

Figure 7. DORs stabilized by DPDPE and SNC-80 distinctively interact with $\beta$ arr2. HEK293 cells were transfected with recombinant plasmids for the BRET pairs and accessory proteins as indicated in the figure to assess $\beta$ arr2 recruitment from the vantage point or the receptor $(A, B)$ or the $G \beta \gamma$ dimer $(\boldsymbol{C}, \boldsymbol{D}) . \boldsymbol{A}, 0$ n the day of experiment, HEK293cells were suspended in PBS and distributed into a microplate following which they were introduced into the plate reader and incubated with coelanterazine for 5 min before adding DPDPE or SNC-80 (1 $\mu \mathrm{M})$. BRET1 measures were obtained every $18 \mathrm{~s}$ following agonist addition. Data correspond to one of three independent experiments. $\boldsymbol{B}$, HEK293 cells were incubated with DPDPE or SNC $-80\left(1 \mu \mathrm{m} ; 37^{\circ} \mathrm{C}\right)$ before resuspending them in PBS and taking BRET1 readings 5 min after manual addition of coelenterazine $h$. Results were expressed as the difference between netBRET values obtained in vehicle and agonist-treated cells and correspond to mean \pm SEM of at least five independent experiments. NetBRET values obtained in vehicle-treated cells: $0.021 \pm 0.004$. Statistical comparisons were done by repeated measures one-way ANOVA on netBRET values. $\left(F_{(4,16)}=262.3\right.$, $p<0.001)$ using Bonferroni for post hoc comparisons: ${ }^{* * *} p<0.001$ comparing drugs to vehicle; $\#<0.001$ comparing DPDPE versus SNC-80. C, Cells were processed as in $A$ and BRET measures similarly taken. $\boldsymbol{D}$, Treatment, BRET measures, expression of results, and statistical analyses were performed as in $B$. Results correspond to mean \pm SEM of five independent. netBRET values in vehicle-treated cells: $0.019 \pm 0.002$. Repeated measures one-way ANOVA $\left(F_{(4,16)}=23.6, p<0.001\right)$, using Bonferroni for post hoc comparisons: ${ }^{* * *} p<0.001$ comparing SNC-80 to vehicle; ${ }^{\#} p<0.001$ comparing DPDPE versus SNC-80.

changes at the DOR-G $\beta \gamma$ interface. Results from these experiments are shown in Figure 8, $E$ and $F$, and indicate that SNC-80 and DPDPE conserved their ability to respectively increase or reduce the BRET signal generated by DOR-Luc/YFP-G $\gamma 2$. Furthermore, only DPDPE allowed this BRET pair to attain prestimulation values during recovery (Fig. $8 D$ ). Thus, together, observations obtained with these three BRET pairs indicate that receptor activation by SNC- 80 induced a stable DOR-G $\beta \gamma$ - $\beta$ arr2 association while DPDPE induced a transient interaction between the receptor and the regulatory protein.

To confirm observations obtained using BRET technology, we performed coimmunopurification assays in which we assessed how DPDPE and SNC-80 modified the amount of $\beta$ arr2-Luc and YFP-G $\gamma 2$ that copurified with Flag-DORs. Purifications were performed either immediately after receptor stimulation (30 min, $1 \mu \mathrm{M}$ ) or following 30 min recovery in the absence of ligand (Fig. 9). Consistent with in vivo observations, stimulation by SNC-80 resulted in increased recovery of G $\gamma 2$-YFP and $\beta$ arr2Luc (Fig. 9A), while incubation with DPDPE only increased the amount of $\beta$ arr2 associated to the receptor (Fig. 9B). Copurifica-
ßarr2-Luc/DOR-YFP/Gai1ß1Y2
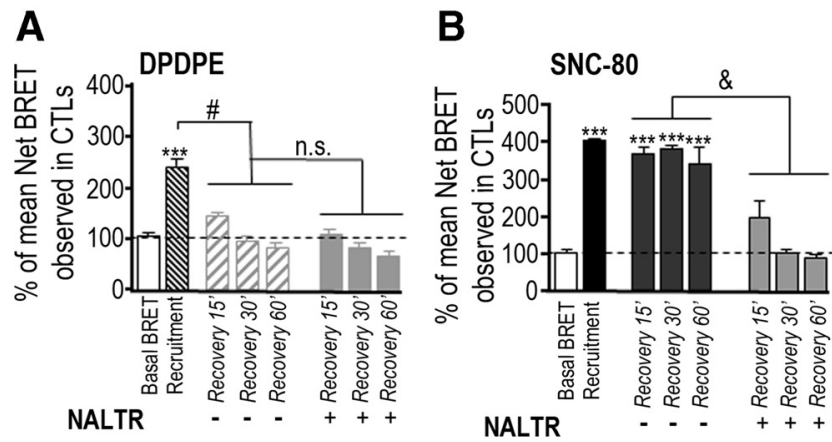

ßarr2-Luc/YFP-GY2/Flag-DOR/Gai1/G $\beta 1$
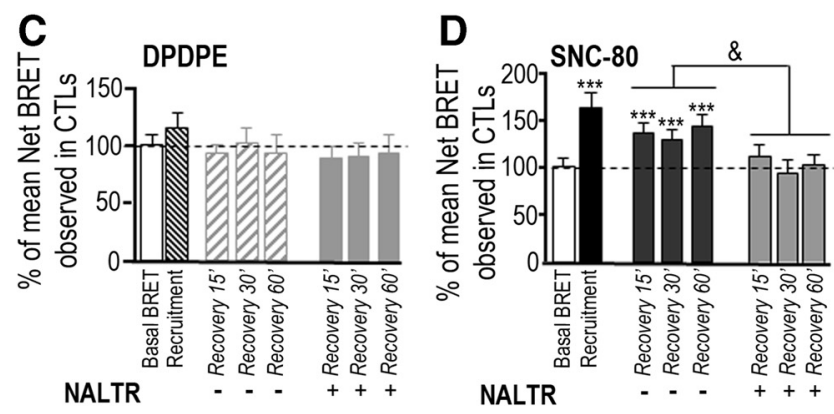

DOR-Luc/YFP-GY2/Gai/GB1//arr2
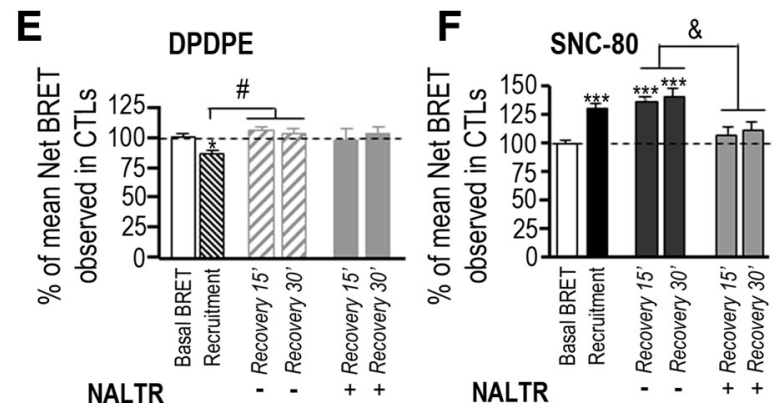

Figure 8. The duration of $\beta$ arr2 association with DOR-G $\beta \gamma$ complexes depends on the activating agonist. HEK293 cells were transfected with recombinant plasmids for the indicated BRET pairs and accessory proteins. On the day of the experiment, they were exposed to $1 \mu \mathrm{M}$ DPDPE $(\boldsymbol{A}, \boldsymbol{C}, \boldsymbol{E})$ or SNC-80 (B, D, F) for $30 \mathrm{~min}$. Treatment was stopped and cells washed by addition of $P B S$, following which they were either immediately used for BRET measures or were first allowed to recover in presence or absence of naltrindole $(1 \mu \mathrm{M})$ for the indicated periods of time. BRET1 readings were taken 5 min after manual addition of coelenterazine. All data are expressed as percentage of mean netBRET values observed in vehicle-treated controls, and correspond to mean \pm SEM of three to six independent experiments. Statistical comparisons for each BRET pair were done on netBRET values using repeated measures one-way ANOVA. $\boldsymbol{A}$, $\boldsymbol{B}:\left(F_{(14,56)}=36.7, p<0.001\right),{ }^{\#} p<0.001 ;{ }^{*} p<0.001 ;{ }^{* * *} p<0.001$ comparing treatments to vehicle. $\boldsymbol{C}, \boldsymbol{D}:\left(F_{(14,70)}=20.5, p<0.001\right) ;{ }^{\&} p<0.001 ;{ }^{* * *} p<0.001$ comparing treatments to vehicle. $\boldsymbol{E}, \boldsymbol{F}:\left(F_{(10,20)}=33.9, p<0.001\right)$; ${ }^{\&} p<0.001{ }^{*}{ }^{*} p<0.05,{ }^{* * *} p<0.001$ comparing treatments to vehicle.

tion assays performed following recovery from agonist pretreatment were also consistent with BRET data. Thus, in cells that recovered from exposure to DPDPE, the amount of $\beta$ arr2-Luc that coprecipitated with the receptor was reduced to pretreatment values (Fig. 9B). In contrast, in cells that recovered from exposure to SNC-80, the amounts of $\beta$ arr2-Luc or G $\gamma 2$-YFP that copurified with DORs was not different from those obtained immediately after recruitment (Fig. 9A), thus confirming the stable association of DORs, $G \beta \gamma$, and $\beta$ arr2.

Data analyzed thus far indicate that each agonist caused the receptor $\mathrm{C}$ terminus to distinctively position itself with respect to 
A

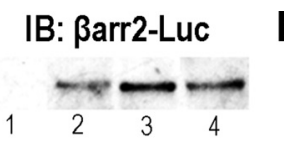

B
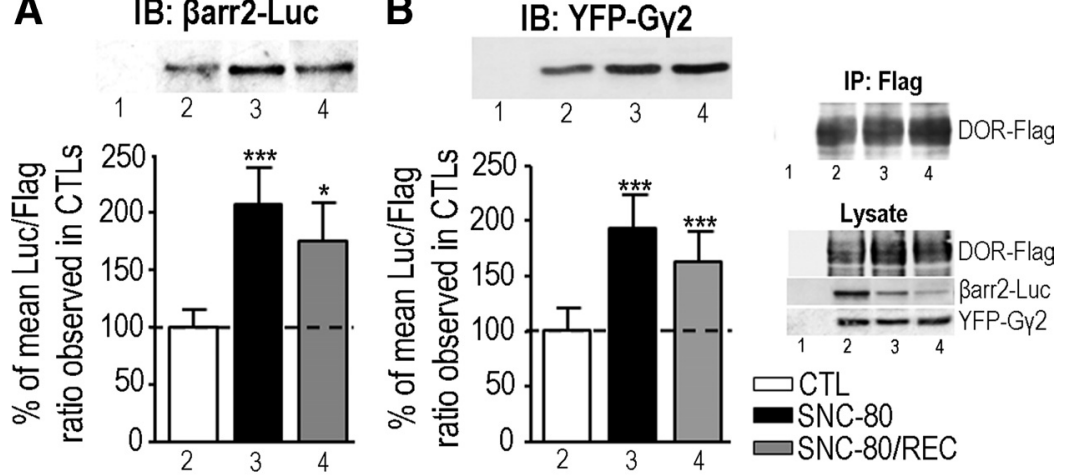

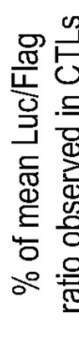

250

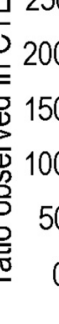

C

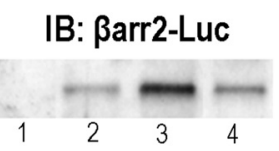

D
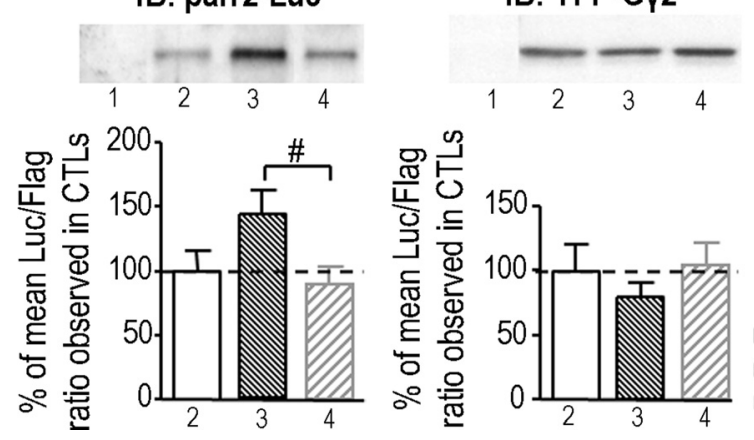

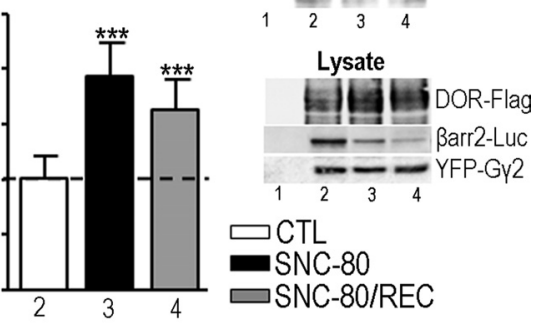

\section{IB: YFP-Gy2}
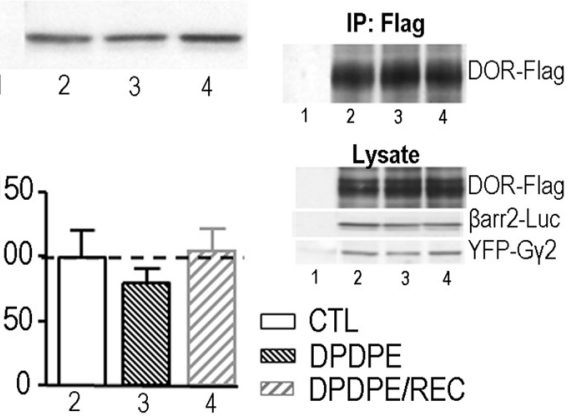

Figure 9. The stability of $\beta$ arr2 association to DOR-G $\beta \gamma$ complexes depends on the activating agonist. HEK 293 cells expressing or not Flag-DORs, $\beta$ arr2-LuC, YFP-G $\gamma 2$, and accessory heterotrimeric $G \alpha$ i1 and $\mathrm{G} \beta 1$ subunits were treated with $1 \mu \mathrm{m}$ SNC-80 ( $\boldsymbol{A}$, B) or DPDPE $(\boldsymbol{C}, \boldsymbol{D})$ for $30 \mathrm{~min}$. At the end of treatment, cells were washed and immediately used in coimmunopurification assays or were first allowed to recover for $30 \mathrm{~min}$ in the absence of agonist. Cells were then lysed, Flag-DORs purified, and the resulting product separated by SDS-PAGE. Blots show representative examples of the amounts of $\beta$ arr2-LuC and YFP-G $\gamma 2$ that were copurified with Flag-DORs in the following: (1) non-transfected HEK293 cells; (2) transfected cells that were not exposed to agonist; (3) transfected cells that were exposed to agonist during $30 \mathrm{~min}$, and (4) transfected cells that were exposed to agonist and then allowed to recover for $30 \mathrm{~min}$ in the absence of ligand. Insets show control blots of proteins amounts present in lysates before immunopurification and amount of Flag-DOR immunopurified for each sample. Histograms show results obtained by compiling densitometric measures of eight independent experiments. Data are expressed as percentage of $\beta$ arr2-Luc/Flag-DOR or YFP-G $\gamma 2 /$ Flag-DOR ratios in controls. Statistical comparisons of immunoreactivity ratios were done by repeated measures one-way ANOVA. Barr2-Luc association with Flag-DORs $(\boldsymbol{A}, \boldsymbol{C}):\left(F_{(4,28)}=10.0, p<0.001\right) ;{ }^{*} p<0.05,{ }^{* *} p<0.01$ comparing treatments to vehicle; ${ }^{\#} p<0.05$ comparing $\beta$ arr2-Luc/Flag-DORs ratios following recovery or not from DPDPE treatment. YFP-G $\gamma 2$ association with Flag-DORs $(\boldsymbol{B}, \boldsymbol{D}):\left(F_{(4,28)}=13.8, p<0.001\right) ;{ }^{*} p<0.05 ;{ }^{* *} p<0.01$ comparing treatments to vehicle.

the G $\beta \gamma$ dimer. SNC-80 caused $\beta$ arr 2 to be recruited in the proximity of the N-terminal domain of $\mathrm{G} \gamma 2$ and was accompanied by stable $\beta$ arr2 association to the receptor and poor recycling. In the case of DPDPE, $\beta$ arr2 did not approach the BRET tag present in $\mathrm{G} \gamma 2$, and its association to the receptor was transient. Moreover, kinetics of DOR- $\beta$ arr2 dissociation $\left(t_{1 / 2}=12 \mathrm{~min}\right)$ were similar to those of receptor recycling $\left(t_{1 / 2}=12 \mathrm{~min}\right)$, suggesting a correlation between recycling and $\beta$ arr2 dissociation upon DPDPE removal. The C-terminal domain of DORs has been previously shown to actively contribute to DOR recycling (Zhang et al., 2008; Trapaidze et al., 2000), raising the possibility that distinct positioning of the $\mathrm{C}$ terminus by the two agonists could lead to differential stability of DOR- $\beta$ arr2 interactions. If this were the case, changing the orientation of the receptor $\mathrm{C}$ terminus should modify the stability with which DORs activated by SNC-80 associate with $\beta$ arr2. To test this assumption we assessed whether naltrindole $(1 \mu \mathrm{M})$, the ligand that only modified DOR-G $\gamma 2$ interaction induced by SNC-80 (Fig. 5C), had any effect on the stability of the DOR-G $\beta \gamma$ - $\beta$ arr 2 complex promoted by this agonist. The effect of naltrindole on BRET signals generated by the different pairs of interest is shown to the right hand side of each series of SNC-80 histograms presented in Figure $8 B, D, E$.
The presence of the antagonist during recovery from exposure to SNC-80 caused the DOR-G $\gamma 2$ - $\beta$ arr2 complex to fall apart, as indicated by the recovery of pretreatment BRET signals at pairs monitoring different interactions within the complex (Fig. $8 B, D, F$ ). In contrast, the addition of naltrindole to cells recovering from exposure to DPDPE was without effect at each of the BRET pairs tested (Fig. $8 A, C, E)$.

Finally, we reasoned that if the ability to induce a stable DOR- $\beta$ arr2 association was contributing to poor recycling by SNC-80, then introducing naltrindole during recovery from treatment should not only destabilize the DOR-G $\beta \gamma$ - $\beta$ arr2 complex but also rescue recycling. Figure $10 \mathrm{~A}$ shows that naltrindole $(1 \mu \mathrm{M})$ was able to rescue DOR recycling in SNC-80 treated cells, an effect that was mimicked by the antagonist naloxone $(1 \mu \mathrm{M})$, but not by the agonist morphine $(10 \mu \mathrm{M})$. On the other hand, naltrindole did not modify DOR recycling by DPDPE, an observation that was consistent with naltrindole's lack of effect on DOR- $\beta$ arr2 interaction that was promoted by this agonist.

\section{Discussion}

Results obtained in this study indicate that agonist ability to support DOR recycling was associated with distinct degrees of receptor desensitization and different potential for inducing acute analgesic tolerance. Differences in recycling were supported by the adoption of agonist-specific conformations whose distinctive interaction with $\mathrm{G} \beta \gamma$ subunits led to specific modalities of $\beta$ arr2 recruitment by DOR/ $\mathrm{G} \beta \gamma$ complexes.

\section{DORs adopt agonist-specific conformations}

The idea that ligand-specific trafficking could determine opioid potential for generating tolerance has raised considerable attention since this type of bias could provide the basis for developing opioid ligands with longer lasting analgesic actions. However, to design this type of ligands, a better understanding of the molecular determinants of biased trafficking is needed. In fact, although agonist-specific conformations are currently recognized as the molecular bases of functional bias (Urban et al., 2007; Kenakin, 2007), there is little knowledge of how agonist-specific receptor states may determine distinct trafficking patterns elicited by different agonists. In the present study, we showed that sustained activation by SNC-80 and DPDPE resulted in the stabilization of receptors states in which the receptor $\mathrm{C}$ terminus adopted different spatial orientations. Such differences were revealed by ligand-specific BRET changes at a biosensor monitoring DOR interaction with the $G \beta \gamma$ dimer. At this interface, SNC-80 and DPDPE were respectively shown to approach or separate the $\mathrm{C}$-terminal end of the receptor and the N-terminal domain of $\mathrm{G} \gamma 2$, indicating distinct conformational changes by each agonist. 

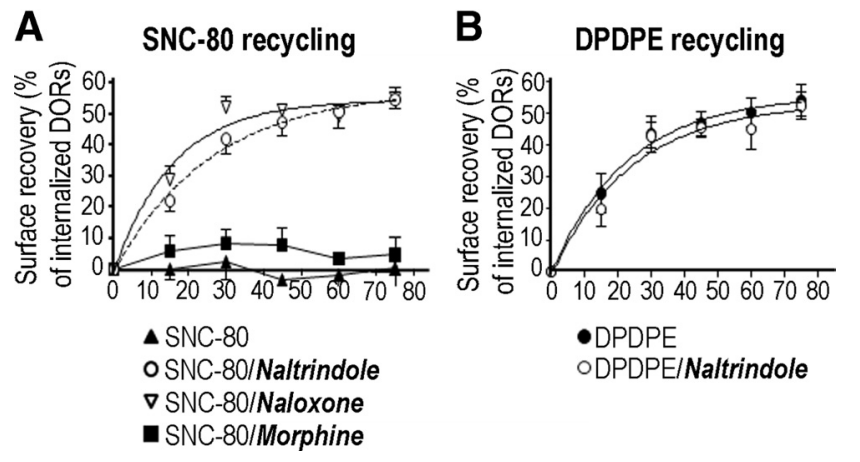

Figure 10. Naltrindole allows us to rescue DOR recycling following SNC-80 exposure. HEK293 cells stably expressing wild-type DORs were incubated with SNC-80 (A) or DPDPE ( $\boldsymbol{B} ; 1$ $\mu \mathrm{M}, 30 \mathrm{~min}$ ) to induce internalization. At the end of treatment, cells were washed to remove agonist and allowed to recover for the indicated periods of time in the presence or absence of the indicated ligands. At the end of each recovery period, membrane receptors were assessed using an ELISA-based method. Receptors recovered at the membrane were expressed as percentage of internalized DORs and represent mean \pm SEM of 4-9 independent experiments. Data were analyzed with mixed two-way ANOVA. $A$, Time $\times$ treatment interaction for SNC-80 $\left(F_{(15,156)}=\right.$ $4.3, p<0.001)$; using Bonferroni for post hoc comparisons: $p<0.001$ comparing SNC-80 to SNC-80 + naloxone or to SNC-80 + naltrindole; $p>0.05$ comparing SNC-80 to SNC-80 + morphine. $B$, No time $\times$ treatment interaction was observed for DPDPE $\left(F_{(5,48)}=0.4, p>\right.$ $0.05), p>0.05$ comparing DPDPE to DPDPE + naltrindole.

The notion that the population of cellular DORs was distinctively modified by each agonist was also supported by binding data. On the one hand, the conservation of $\left[{ }^{3} \mathrm{H}\right]$ naltrindole binding capacity following exposure to SNC-80 indicated that the total number of DORs and their ability to recognize the radioligand was unaffected by treatment with this agonist. On the other hand, pretreatment with DPDPE caused a reduction in $B_{\max }$ that was not determined by downregulation of receptor protein. The fact that naltrindole's apparent affinity for the receptor remained unchanged indicated that the decrease in $B_{\max }$ could neither be explained by lingering free agonist. It is also unlikely that slow dissociation kinetics may have accounted for $B_{\max }$ reduction by DPDPE. Actually, if slow agonist dissociation were the basis for the loss of naltrindole binding sites, $k_{\text {off }}$ values would predict a $B_{\max }$ reduction by both agonists (Knapp et al., 1991, 1996). Furthermore, based on dissociation kinetics, SNC-80 would be expected to produce a greater loss of $\left[{ }^{3} \mathrm{H}\right]$ naltrindole binding sites than DPDPE, which was clearly not the case since treatment with SNC-80 did not modify radioligand binding. Alternatively, the DPDPE-dependent decrease in Bmax may have resulted from the adoption of a conformation that was poorly recognized by $\left[{ }^{3} \mathrm{H}\right]$ naltrindole. Data showing that naltrindole-induced BRET changes at the DOR-G $\gamma 2$ interface were much smaller in cells that had been pretreated with DPDPE than SNC-80 support this line of thinking. Differential recognition of the radioligand could have been determined by DPDPE and SNC-80 distinctively modifying receptor ability to isomerize into $\left[{ }^{3} \mathrm{H}\right]$ naltrindole-binding conformations. Changes in DOR isomerization constants have been previously reported following prolonged incubation with other DOR ligands ( $\mathrm{Pi}$ ñeyro et al., 2001). Furthermore, it is also possible that each agonist may have caused receptors to traffic to different subcellular compartments, which need not be equally accessible to the radioligand probe. Differences in isomerization and/or sorting could both be determined by the distinct DOR-G $\beta \gamma$ $\beta$ arr2 interactions promoted by each agonist.

\section{Distinct modalities of $\boldsymbol{\beta}$ arr 2 recruitment support agonist- related differences in recycling}

Barrs interact both with the C-terminal domain and intracellular loops of GPCRs (Hanson and Gurevich, 2006; Bennett et al., 2000). For example, $\beta$ arrs may associate with the second intracellular loop of the receptor and displace $\mathrm{G} \alpha$ (Krupnick et al., 1997). In doing so they provide a mechanism that supports the classical idea of $\beta$ arrs causing desensitization by disrupting the physical association between receptor and $G$ protein. In keeping with this notion and with previous reports (Okura et al., 2003; Galés et al., 2005; Ayoub et al., 2007), sustained exposure to DPDPE or SNC-80 both reduced the spontaneous BRET signal generated by the G $\alpha$ i-Luc/DOR-GFP pair by more than two thirds. On the other hand, we found that DOR interaction with the $G \beta \gamma$ dimer persisted during prolonged periods of agonist stimulation. In fact, $60 \mathrm{~min}$ exposure to SNC-80 increased the basal signal at the DOR-Luc/GFP-G $\gamma 2$ pair, indicating not only that DORs and $\mathrm{G} \beta \gamma$ subunits remained in close proximity of one another, but that the receptor $\mathrm{C}$ terminus was drawn closer to $\mathrm{G} \gamma 2$. The decrease in energy transfer that was caused by DPDPE at the same BRET pair was a low percentage of the spontaneous signal $(\leq 10 \%)$, and as such more akin to a conformational rearrangement than to a disruption of preexisting DOR-G $\beta \gamma$ complexes (Audet et al., 2008). Previous studies have shown that opioid receptors remain associated to $G \beta \gamma$ subunits during recruitment of G-protein receptor kinases (Li et al., 2003). Data provided herein indicate that DOR/G $\beta \gamma$ association may persist into subsequent steps of the desensitization cascade, during $\beta$ arr recruitment and even later on, after receptor uncoupling from $\mathrm{G} \alpha$ has taken place.

The G $\beta \gamma$ dimer directly interacts with GPCRs (El Far et al., 2001; Mahon et al., 2006). This association does not necessarily involve the same residues as those implicated in $\beta$ arr recruitment (Kouhen et al., 2000; Qiu et al., 2007), conferring receptors the ability to simultaneously associate both with $\beta$ arrs and $\mathrm{G} \beta \gamma$. Conversely, $\beta$ arrs may interact with $\mathrm{G} \beta$ subunits (Yang et al., 2009) through residues that do not necessarily contribute to $\mathrm{G} \beta$ association to the receptor (Hanson and Gurevich, 2006; Mahon et al., 2006), thus allowing for the regulatory protein to simultaneously associate with receptors and the G $\beta \gamma$ dimer. BRET and coimmunopurification data obtained in this study are consistent with such scenario because both DOR agonists promoted $\beta$ arr 2 recruitment to receptors that remained at least partly associated to the $\mathrm{G} \beta \gamma$ dimer. However, only SNC-80 supported recruitment of $\beta$ arr2 in close proximity of the N-terminal domain of $\mathrm{G} \gamma 2$, underscoring a role for DOR-G $\beta \gamma$ complexes in establishing ligand-specific interactions with regulatory proteins. $\mathrm{G} \beta \gamma$ contribution to producing ligand-specific modalities of DOR- $\beta$ arr 2 association was further evidenced by results obtained with naltrindole. Indeed, this antagonist caused the receptor $\mathrm{C}$ terminus to move away from $\mathrm{G} \gamma 2$ and destabilized the DOR- $\beta$ arr2 interaction promoted by SNC-80. The antagonist was without effect on the stability of DOR- $\beta$ arr2 association by DPDPE, which did not involve $G \gamma 2$ in the first place. Together with conformational changes that disrupted the DOR-G $\beta \gamma$ - $\beta$ arr 2 complex, naltrindole changed the recycling phenotype of the conformation stabilized by SNC-80 into one that resembled recycling elicited by DPDPE. The interconversion from one conformational/functional phenotype to the other provides a causal link between the conformations stabilized by different ligands and their distinct recycling profiles. 


\section{Agonist-specific recycling patterns determine differences in DOR desensitization, and are predictive of agonist potential for inducing acute analgesic tolerance}

Previous studies have shown that different internalization patterns could contribute to agonist differences in producing DOR desensitization and analgesic tolerance (Pradhan et al., 2009, 2010). Here, we showed that desensitization and acute analgesic tolerance produced by DPDPE and SNC- 80 were quite distinct despite similar ability to induce DOR internalization. On the other hand, tendency to induce acute tolerance was inversely correlated with agonist ability to induce recycling. In particular, the non-recycling agonist SNC-80 produced acute analgesic tolerance that was absent in mice treated with the recycling agonist DPDPE. We have also shown that recycling mitigated desensitization caused by DPDPE but not SNC-80. Since desensitization is thought to actively contribute to the development of acute tolerance (Bohn et al., 2004; Christie, 2008; Nagi and Piñeyro, 2011), it is tempting to speculate that acute analgesic tolerance may result from distinct recycling patterns that determine agonist ability to induce desensitization. On the other hand, Pradhan et al. (2010) have clearly demonstrated that the tendency to induce chronic analgesic tolerance is not necessarily dependent on agonist ability to induce DOR desensitization.

Although DOR ability to undergo recycling has been frequently reported (Trapaidze et al., 2000; Zhang et al., 2008; Archer-Lahlou et al., 2009), these receptors have also been described as being committed for degradation via interaction with G-protein coupled receptor associated sorting proteins (GASPs) (Whistler et al., 2002; Hislop et al., 2009). The data obtained in this study allows reconciling both types of observations by showing that post-endocytic trafficking might not be a fixed property of the receptor, but a quality determined by the adoption of agonist-specific conformations. In this sense, it is interesting to note that GASPs' ability to target opioid receptors for downregulation is subject to conformational restrains (Thompson et al., 2007).

In summary, the data presented in this study shows that recycling patterns that result from stabilization of agonist-specific conformations are predictive of analgesic tolerance. These observations are consistent with the notion that development of biased agonists that favor recycling may help produce novel, longer acting opioid analgesics.

\section{References}

Archer-Lahlou E, Audet N, Amraei MG, Huard K, Paquin-Gobeil M, Pineyro G (2009) Src promotes delta opioid receptor (DOR) desensitization by interfering with receptor recycling. J Cell Mol Med 13:147-163.

Arttamangkul S, Quillinan N, Low MJ, von Zastrow M, Pintar J, Williams JT (2008) Differential activation and trafficking of micro-opioid receptors in brain slices. Mol Pharmacol 74:972-979.

Audet N, Piñeyro G (2011) Using BRET to detect ligand-specific conformational changes in performed signalling complexes. Methods Mol Biol 756:149-163.

Audet N, Paquin-Gobeil M, Landry-Paquet O, Schiller PW, Piñeyro G (2005) Internalization and Src activity regulate the time course of ERK activation by delta opioid receptor ligands. J Biol Chem 280:7808-7816.

Audet N, Galés C, Archer-Lahlou E, Vallières M, Schiller PW, Bouvier M, Pineyro G (2008) Bioluminescence resonance energy transfer assays reveal ligand-specific conformational changes within preformed signaling complexes containing delta-opioid receptors and heterotrimeric $\mathrm{G}$ proteins. J Biol Chem 283:15078-15088.

Ayoub MA, Maurel D, Binet V, Fink M, Prézeau L, Ansanay H, Pin JP (2007) Real-time analysis of agonist-induced activation of protease-activated receptor $1 /$ Galphail protein complex measured by bioluminescence resonance energy transfer in living cells. Mol Pharmacol 71:1329-1340.

Azzi M, Charest PG, Angers S, Rousseau G, Kohout T, Bouvier M, Piñeyro G
(2003) Beta-arrestin-mediated activation of MAPK by inverse agonists reveals distinct active conformations for $\mathrm{G}$ protein-coupled receptors. Proc Natl Acad Sci U S A 100:11406-11411.

Barak LS, Salahpour A, Zhang X, Masri B, Sotnikova TD, Ramsey AJ, Violin JD, Lefkowitz RJ, Caron MG, Gainetdinov RR (2008) Pharmacological characterization of membrane-expressed human trace amine-associated receptor 1 (TAAR1) by a bioluminescence resonance energy transfer cAMP biosensor. Mol Pharmacol 74:585-594.

Beaudry H, Proteau-Gagné A, Li S, Dory Y, Chavkin C, Gendron L (2009) Differential noxious and motor tolerance of chronic delta opioid receptor agonists in rodents. Neuroscience 161:381-391.

Bennett TA, Maestas DC, Prossnitz ER (2000) Arrestin binding to the G protein-coupled $\mathrm{N}$-formyl peptide receptor is regulated by the conserved "DRY" sequence. J Biol Chem 275:24590-24594.

Bohn LM, Lefkowitz RJ, Gainetdinov RR, Peppel K, Caron MG, Lin FT (1999) Enhanced morphine analgesia in mice lacking beta-arrestin 2. Science 286:2495-2498.

Bohn LM, Gainetdinov RR, Lin FT, Lefkowitz RJ, Caron MG (2000) Muopioid receptor desensitization by beta-arrestin-2 determines morphine tolerance but not dependence. Nature 408:720-723.

Bohn LM, Lefkowitz RJ, Caron MG (2002) Differential mechanisms of morphine antinociceptive tolerance revealed in (beta)arrestin-2 knockout mice. J Neurosci 22:10494-10500.

Bohn LM, Dykstra LA, Lefkowitz RJ, Caron MG, Barak LS (2004) Relative opioid efficacy is determined by the complements of the G proteincoupled receptor desensitization machinery. Mol Pharmacol 66:106-112.

Boussif O, Lezoualc'h F, Zanta MA, Mergny MD, Scherman D, Demeneix B, Behr JP (1995) A versatile vector for gene and oligonucleotide transfer into cells in culture and in vivo: polyethylenimine. Proc Natl Acad Sci U S A 92:7297-7301.

Bradbury FA, Zelnik JC, Traynor JR (2009) G protein independent phosphorylation and internalization of the delta-opioid receptor. J Neurochem 109:1526-1535.

Breit A, Gagnidze K, Devi LA, Lagacé M, Bouvier M (2006) Simultaneous activation of the delta opioid receptor (deltaOR)/sensory neuron-specific receptor-4 (SNSR-4) hetero-oligomer by the mixed bivalent agonist bovine adrenal medulla peptide 22 activates SNSR- 4 but inhibits deltaOR signaling. Mol Pharmacol 70:686-696.

Cahill CM, Holdridge SV, Morinville A (2007) Trafficking of delta-opioid receptors and other G-protein-coupled receptors: implications for pain and analgesia. Trends Pharmacol Sci 28:23-31.

Chaplan SR, Bach FW, Pogrel JW, Chung JM, Yaksh TL (1994) Quantitative assessment of tactile allodynia in the rat paw. J Neurosci Methods 53:55-63.

Christie MJ (2008) Cellular neuroadaptations to chronic opioids: tolerance, withdrawal and addiction. Br J Pharmacol 154:384-396.

Dang VC, Christie MJ (2012) Mechanisms of rapid opioid receptor desensitization, resensitization and tolerance in brain neurons. $\mathrm{Br} \mathrm{J}$ Pharmacol 165:1704-1716.

Dang VC, Chieng B, Azriel Y, Christie MJ (2011) Cellular morphine tolerance produced by betaarrestin-2-dependent impairment of mu-opioid receptor resensitization. J Neurosci 31:7122-7130.

Decosterd I, Woolf CJ (2000) Spared nerve injury: an animal model of persistent peripheral neuropathic pain. Pain 87:149-158.

Dworkin RH (2009) Introduction: recommendations for the diagnosis, assessment, and treatment of neuropathic pain. Am J Med 122:S1-S2.

El Far O, Bofill-Cardona E, Airas JM, O’Connor V, Boehm S, Freissmuth M, Nanoff C, Betz H (2001) Mapping of calmodulin and Gbetagamma binding domains within the C-terminal region of the metabotropic glutamate receptor 7A. J Biol Chem 276:30662-30669.

Fasano C, Thibault D, Trudeau LE (2008) Culture of postnatal mesencephalic dopamine neurons on an astrocyte monolayer. Curr Protoc Neurosci Chapter 3:Unit 3.21.

Galés C, Rebois RV, Hogue M, Trieu P, Breit A, Hébert TE, Bouvier M (2005) Real-time monitoring of receptor and G-protein interactions in living cells. Nat Methods 2:177-184.

Galés C, Van Durm JJ, Schaak S, Pontier S, Percherancier Y, Audet M, Paris H, Bouvier M (2006) Probing the activation-promoted structural rearrangements in preassembled receptor-G protein complexes. Nat Struct Mol Biol 13:778-786

Gaveriaux-Ruff C, Nozaki C, Nadal X, Hever XC, Weibel R, Matifas A, Reiss D, Filliol D, Nassar MA, Wood JN, Maldonado R, Kieffer BL (2011) 
Genetic ablation of delta opioid receptors in nociceptive sensory neurons increases chronic pain and abolishes opioid analgesia. Pain 152:1238-1248.

Gomes I, Jordan BA, Gupta A, Trapaidze N, Nagy V, Devi LA (2000) Heterodimerization of $\mathrm{mu}$ and delta opioid receptors: A role in opiate synergy. J Neurosci 20:RC110.

Hamdan FF, Rochdi MD, Breton B, Fessart D, Michaud DE, Charest PG, Laporte SA, Bouvier M (2007) Unraveling G protein-coupled receptor endocytosis pathways using real-time monitoring of agonist-promoted interaction between beta-arrestins and AP-2. J Biol Chem 282:29089-29100.

Hanson SM, Gurevich VV (2006) The differential engagement of arrestin surface charges by the various functional forms of the receptor. J Biol Chem 281:3458-3462.

Hislop JN, Henry AG, Marchese A, von Zastrow M (2009) Ubiquitination regulates proteolytic processing of $\mathrm{G}$ protein-coupled receptors after their sorting to lysosomes. J Biol Chem 284:19361-19370.

Hylden JL, Wilcox GL (1980) Intrathecal morphine in mice: a new technique. Eur J Pharmacol 67:313-316.

Kenakin T (2007) Functional selectivity through protean and biased agonism: who steers the ship? Mol Pharmacol 72:1393-1401.

Kenakin T, Miller LJ (2010) Seven transmembrane receptors as shapeshifting proteins: the impact of allosteric modulation and functional selectivity on new drug discovery. Pharmacol Rev 62:265-304.

Kim JA, Bartlett S, He L, Nielsen CK, Chang AM, Kharazia V, Waldhoer M, Ou CJ, Taylor S, Ferwerda M, Cado D, Whistler JL (2008) Morphineinduced receptor endocytosis in a novel knockin mouse reduces tolerance and dependence. Curr Biol 18:129-135.

Knapp RJ, Sharma SD, Toth G, Duong MT, Fang L, Bogert CL, Weber SJ, Hunt M, Davis TP, Wamsley JK (1991) [D-Pen2,4'-125I-Phe4,DPen5]enkephalin: a selective high affinity radioligand for delta opioid receptors with exceptional specific activity. J Pharmacol Exp Ther 258:1077-1083.

Knapp RJ, Santoro G, De Leon IA, Lee KB, Edsall SA, Waite S, Malatynska E, Varga E, Calderon SN, Rice KC, Rothman RB, Porreca F, Roeske WR, Yamamura HI (1996) Structure-activity relationships for SNC80 and related compounds at cloned human delta and mu opioid receptors. J Pharmacol Exp Ther 277:1284-1291.

Kouhen OM, Wang G, Solberg J, Erickson LJ, Law PY, Loh HH (2000) Hierarchical phosphorylation of delta-opioid receptor regulates agonistinduced receptor desensitization and internalization. J Biol Chem 275:36659-36664.

Krupnick JG, Gurevich VV, Benovic JL (1997) Mechanism of quenching of phototransduction. Binding competition between arrestin and transducin for phosphorhodopsin. J Biol Chem 272:18125-18131.

Leduc M, Breton B, Galés C, Le Gouill C, Bouvier M, Chemtob S, Heveker N (2009) Functional selectivity of natural and synthetic prostaglandin EP4 receptor ligands. J Pharmacol Exp Ther 331:297-307.

Li J, Xiang B, Su W, Zhang X, Huang Y, Ma L (2003) Agonist-induced formation of opioid receptor-G protein-coupled receptor kinase (GRK)-G beta gamma complex on membrane is required for GRK2 function in vivo. J Biol Chem 278:30219-30226.

Lowe JD, Celver JP, Gurevich VV, Chavkin C (2002) mu-Opioid receptors desensitize less rapidly than delta-opioid receptors due to less efficient activation of arrestin. J Biol Chem 277:15729-15735.

Madia PA, Dighe SV, Sirohi S, Walker EA, Yoburn BC (2009) Dosing protocol and analgesic efficacy determine opioid tolerance in the mouse. Psychopharmacology 207:413-422.

Mahon MJ, Bonacci TM, Divieti P, Smrcka AV (2006) A docking site for G protein betagamma subunits on the parathyroid hormone 1 receptor supports signaling through multiple pathways. Mol Endocrinol 20:136-146.

Martini L, Whistler JL (2007) The role of mu opioid receptor desensitization and endocytosis in morphine tolerance and dependence. Curr Opin Neurobiol 17:556-564.

Millecamps M, Laferrière A, Ragavendran JV, Stone LS, Coderre TJ (2010) Role of peripheral endothelin receptors in an animal model of complex regional pain syndrome type 1 (CRPS-I). Pain 151:174-183.

Molinari P, Vezzi V, Sbraccia M, Grò C, Riitano D, Ambrosio C, Casella I, Costa T (2010) Morphine-like opiates selectively antagonize receptorarrestin interactions. J Biol Chem 285:12522-12535.
Nadal X, Baños JE, Kieffer BL, Maldonado R (2006) Neuropathic pain is enhanced in delta-opioid receptor knockout mice. Eur J Neurosci 23:830-834.

Nagi K, Piñeyro G (2011) Regulation of opioid receptor signalling: implications for the development of analgesic tolerance. Mol Brain 4:25.

Oakley RH, Laporte SA, Holt JA, Barak LS, Caron MG (1999) Association of beta-arrestin with $G$ protein-coupled receptors during clathrin-mediated endocytosis dictates the profile of receptor resensitization. J Biol Chem 274:32248-32257.

Okura T, Varga EV, Hosohata Y, Navratilova E, Cowell SM, Rice K, Nagase H, Hruby VJ, Roeske WR, Yamamura HI (2003) Agonist-specific downregulation of the human delta-opioid receptor. Eur J Pharmacol 459:9-16.

Piñeyro G, Azzi M, De Léan A, Schiller P, Bouvier M (2001) Short-term inverse-agonist treatment induces reciprocal changes in delta-opioid agonist and inverse-agonist binding capacity. Mol Pharmacol 60:816-827.

Pradhan AA, Becker JA, Scherrer G, Tryoen-Toth P, Filliol D, Matifas A, Massotte D, Gavériaux-Ruff C, Kieffer BL (2009) In vivo delta opioid receptor internalization controls behavioral effects of agonists. PLoS One 4:e5425.

Pradhan AA, Walwyn W, Nozaki C, Filliol D, Erbs E, Matifas A, Evans C, Kieffer BL (2010) Ligand-directed trafficking of the delta-opioid receptor in vivo: two paths toward analgesic tolerance. J Neurosci 30: $16459-16468$.

Qiu Y, Loh HH, Law PY (2007) Phosphorylation of the delta-opioid receptor regulates its beta-arrestins selectivity and subsequent receptor internalization and adenylyl cyclase desensitization. J Biol Chem 282:22315-22323.

Raehal KM, Bohn LM (2011) The role of beta-arrestin2 in the severity of antinociceptive tolerance and physical dependence induced by different opioid pain therapeutics. Neuropharmacology 60:58-65.

Scherrer G, Tryoen-Tóth P, Filliol D, Matifas A, Laustriat D, Cao YQ, Basbaum AI, Dierich A, Vonesh JL, Gavériaux-Ruff C, Kieffer BL (2006) Knockin mice expressing fluorescent delta-opioid receptors uncover $\mathrm{G}$ protein-coupled receptor dynamics in vivo. Proc Natl Acad Sci U S A 103:9691-9696.

Shieh PB, Hu SC, Bobb K, Timmusk T, Ghosh A (1998) Identification of a signaling pathway involved in calcium regulation of BDNF expression. Neuron 20:727-740.

Shields SD, Eckert WA 3rd, Basbaum AI (2003) Spared nerve injury model of neuropathic pain in the mouse: a behavioral and anatomic analysis. J Pain 4:465-470.

Thompson D, Pusch M, Whistler JL (2007) Changes in G protein-coupled receptor sorting protein affinity regulate postendocytic targeting of $\mathrm{G}$ protein-coupled receptors. J Biol Chem 282:29178-29185.

Trapaidze N, Gomes I, Bansinath M, Devi LA (2000) Recycling and resensitization of delta opioid receptors. DNA Cell Biol 19:195-204.

Urban JD, Clarke WP, von Zastrow M, Nichols DE, Kobilka B, Weinstein H, Javitch JA, Roth BL, Christopoulos A, Sexton PM, Miller KJ, Spedding M, Mailman RB (2007) Functional selectivity and classical concepts of quantitative pharmacology. J Pharmacol Exp Ther 320:1-13.

Vargas GA, Von Zastrow M (2004) Identification of a novel endocytic recycling signal in the D1 dopamine receptor. J Biol Chem 279:37461-37469.

Whistler JL, Enquist J, Marley A, Fong J, Gladher F, Tsuruda P, Murray SR, Von Zastrow M (2002) Modulation of postendocytic sorting of $G$ protein-coupled receptors. Science 297:615-620.

Yang M, He RL, Benovic JL, Ye RD (2009) beta-Arrestin1 interacts with the G-protein subunits betalgamma2 and promotes betalgamma2-dependent Akt signalling for NF-kappaB activation. Biochem J 417:287-296.

Zhang J, Barak LS, Anborgh PH, Laporte SA, Caron MG, Ferguson SS (1999) Cellular trafficking of $\mathrm{G}$ protein-coupled receptor/beta-arrestin endocytic complexes. J Biol Chem 274:10999-11006.

Zhang X, Wang F, Chen X, Li J, Xiang B, Zhang YQ, Li BM, Ma L (2005) Beta-arrestin1 and beta-arrestin2 are differentially required for phosphorylation-dependent and -independent internalization of deltaopioid receptors. J Neurochem 95:169-178.

Zhang X, Wang F, Chen X, Chen Y, Ma L (2008) Post-endocytic fates of delta-opioid receptor are regulated by GRK2-mediated receptor phosphorylation and distinct beta-arrestin isoforms. J Neurochem 106:781792. 